4 norden 



\section{Nordiskt samarbete om planering och förvaltning av nordiska havsområden}

Betänkande från ad hoc grupp för havsmiljöförvaltning 
Nordiskt samarbete om planering och förvaltning av nordiska havsområden

Betänkande från ad hoc grupp för havsmiljöförvaltning

TemaNord 2010:504

(C) Nordiska ministerrådet, Köpenhamn 2010

ISBN 978-92-893-1987-4

Tryck: Arco Grafisk A/S

Omslagsfoto: Karin Beate Nøsterud/norden.org, Nikolaj Bock/norden.org,

Klaus Munch Haagensen/norden.org

Upplaga: 500

Tryckt på miljövänligt papper som uppfyller kraven i den nordiska miljösvanemärkningen. Publikationen kan beställas på www.norden.org/order. Fler publikationer på www.norden.org/publikationer

Printed in Denmark

Nordiska ministerrådet

Store Strandstræde 18

DK-1255 Köpenhamn K

Telefon (+45) 33960200

Fax (+45) 33960202

\section{Nordiska rådet}

Store Strandstræde 18

DK-1255 Köpenhamn K

Telefon (+45) 33960400

Fax (+45) 33111870

www.norden.org

\section{Det nordiska samarbetet}

Det nordiska samarbetet är ett av världens mest omfattande regionala samarbeten. Det omfattar Danmark, Finland, Island, Norge och Sverige samt de självstyrande områdena Färöarna, Grönland och Åland.

Det nordiska samarbetet är politiskt, ekonomiskt och kulturellt förankrat och är en viktig partner i europeiskt och internationellt samarbete. Den nordiska gemenskapen arbetar för ett starkt Norden i ett starkt Europa.

Det nordiska samarbetet vill styrka nordiska och regionala intressen och värderingar i en global omvärld. Gemensamma värderingar länderna emellan bidrar till att stärka Nordens ställning som en av världens mest innovativa och konkurrenskraftiga regioner. 


\section{Innehåll}

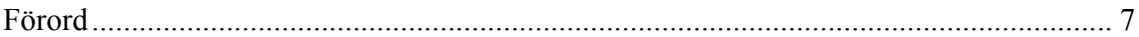

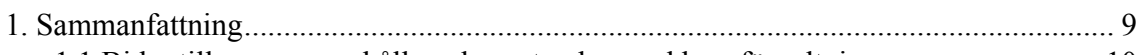

1.1 Bidra till en sammanhållen ekosystembaserad havsförvaltning ......................... 10

1.2 Arbeta aktivt för att utveckla havsplaneringen ................................................. 10

1.3 Verka för pilot- och samarbetsprojekt för förvaltning och planering av havet ..... 10

1.4 Främja utbyte av erfarenheter mellan länder i ett Nordiskt Forum....................... 11

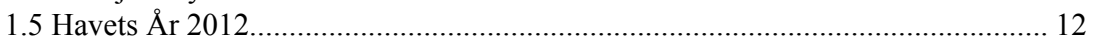

1.6 Främja samarbete och nordiska perspektiv i internationella processer................. 12

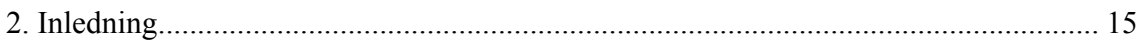

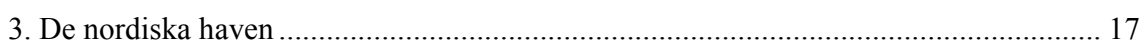

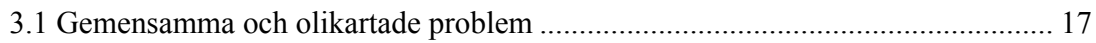

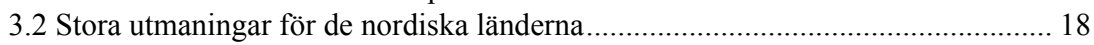

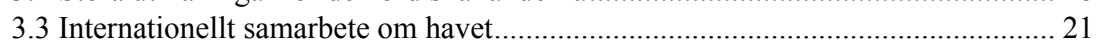

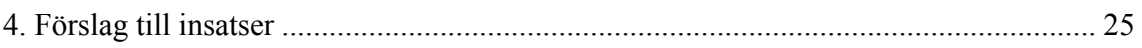

4.1 Bidra till en sammanhållen ekosystembaserad havsförvaltning ......................... 25

4.2 Arbeta aktivt för att utveckla havsplaneringen ................................................. 26

4.3 Verka för pilot- och samarbetsprojekt för förvaltning och planering av havet ..... 27

4.4 Främja utbyte av erfarenheter mellan länder i ett Nordiskt Forum......................... 28

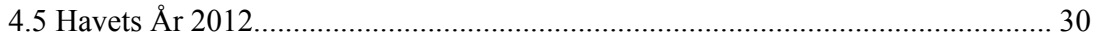

4.6 Främja samarbete och nordiska perspektiv $i$ internationella processer................. 30

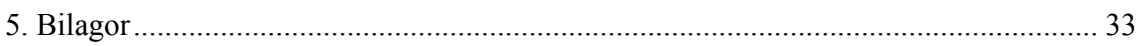

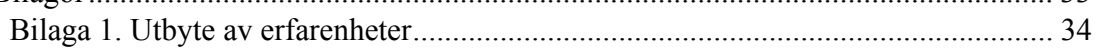

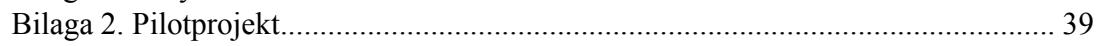

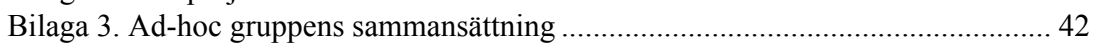

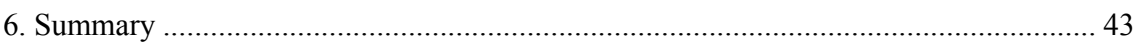

6.1 Contribute to a coherent ecosystem-based marine management .......................... 44

6.2 Work actively to develop maritime planning .................................................... 44

6.3 Work for pilot- and collaboration projects on management and

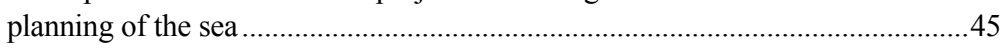

6.4 Promote exchange of experiences between countries in a Nordic Forum............. 45

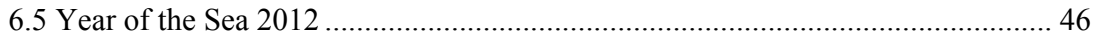

6.6 Promote Cooperation and Nordic Perspective in international processes.............. 46 



\section{Förord}

Miljöministrarna inom Nordiska Ministerrådet beslutade den 4 sept ember 2008 att fördjupa sitt samarbete $\mathrm{o} \mathrm{m}$ de nordiska ha vsområdena samt att ge en ad hoc-arbetsgrupp i uppdrag att utarbeta förslag för utveckling och tydligare nor disk sam ordning av initiat iv till planering, sky dd och förvaltning av ländernas havsområden som omfattar Östersjön, Nordatlanten och delar av Arktis. Sy ftet var att stärk a det nordisk a samarbetet och ge underlag för gemensamma initiativ i nom EU och i andra regionala och internationella sammanhang. Gruppen, som var sa mmansatt av deltagare från alla de nordiska länd erna och de självsty rande områdena, hade tre möten i respektive Stockholm, Köpenhamn och Helsingfors.

Gruppen föreslår i denna rapport att:

- De nordiska länderna bör förstärka sitt samarbete för att skapa en ekosystembaserad och sammanhållen havsförvaltning.

- Nordiska ministerrådet bör verka för att skapa ett ökat samarbete mellan länderna när de utvecklar planeringen av sina havsområden och bör finna fastare former för det samarbetet.

- Ministerrådet bör verka för att havsplaneringen grundas på ekosystemansats och sektorsintegrering samt, för att planeringsinsatserna bli samordnade och för att det utvecklas planeringsmetoder och planeringsunderlag som är tillämpliga för alla nordiska länder.

- Nordiska ministerrådet bör initiera och aktivt stödja pilotprojekt för förvaltning och planering av havet.

- Nordiska ministerrådet bör fortsatt prioritera utvecklandet av havsmiljöförvaltningen efter Ad hoc gruppens avrapportering. Uppdraget bör ges till Akvatiska Ekosystemgruppen (AEG) inom ministerrådets miljösektor.

- Nordiska ministerrådet bör markera havets stora betydelse genom att utlysa 2012 till ett Havets År.

- Nordiska ministerrådet bör verka för att de nordiska medlemsstaterna samarbetar för ett nordiskt perspektiv i EU:s havsarbete och ett effektivare och bättre koordinerat arbete i de regionala konventionerna.

- Nordiska ministerrådet bör arbeta aktivt inom pågående internationella processer om havsplanering för att säkerställa att planeringsprinciperna blir tillämpliga för nordiska förhållanden och att ekosystemansatsen blir grundläggande. 
Ad hoc-grup pen arbetade effektivt und er ett halvår. Som ordförande fö r gruppen vill jag tacka alla so $\mathrm{m}$ deltog $\mathrm{i}$ arbetet för go da insatser. Ett särskilt stort tack riktas till Jens Perus, gruppens sekreterare, so $\mathrm{m}$ gjort beundransvärda insatser. Gruppens försla g till Nordiska ministerrådet är ambitiösa och kräver fortsatt arbete i Ministerrådet och dess arbetsgrupper. Jag vill önska dem som ska följa upp vårt arbete stort lycka till.

Gabriella Lindholm

Havsmiljöambassadör 


\section{Sammanfattning}

Miljöministrarna inom No rdiska ministerrådet beslu tade den 4 september 2008 att fördjupa sitt samarbete och ge en ad hoc-arbetsgrupp i uppdrag att utarbeta förslag för utveckling och ty dligare nordisk samordning av initiativ till $p$ lanering, skydd och fö rvaltning av länd ernas hav sområden som omfattar Ös tersjön, Nord atlanten och delar av Arktis. Sy ftet är att st ärka det nordisk a samarb etet $\mathrm{o}$ ch ge underl ag för gemen samma initiativ ino $\mathrm{m}$ EU och i andra internationella sammanhang. Gruppen skulle särskilt:

- ta initiativ till utbyte och sammanställning av erfarenheter på nationell och regional nivå av ekosystembaserad planering och förvaltning av havs- och kustområden,

- belysa möjligheter till fördjupat samarbete om planering och förvaltning av havs- och kustområden, föreslå hur sådant samarbete kan utvecklas och hur förberedelse inför relevanta internationella processer kan utvecklas,

- undersöka möjligheterna till pilotprojekt för god planering och förvaltning av havsmiljön.

De nordiska havso mrådena är $\mathrm{m}$ ycket omfattande se tt ur e tt e uropeiskt perspektiv och de inneh åller områden av stor miljömässig och ekonomisk betydelse. De nordiska län derna har därför ett stort ansvar för att verka för goda miljöförhållanden och lång siktigt hållbart utnyttjande av resurserna $\mathrm{i}$ dessa hav. Även om länderna kan skilja sig åt $\mathrm{n}$ är det gäll er förvaltningsstruktur, lagstiftning, EU medlemsk ap, resurser och miljöproblem i havet så har de i stort mycket gemensamt i synen på skötseln av hav et resurser och värden. De står alla inför uppgiften att skapa legala ramar, administration och verk tyg som kan göra dem red o att ta sig an de utmaning ar som väntar. Länd erna bör därfö $r$ dra ny tta av varand ras erfarenh eter o ch kunskaper, tillsammans lösa sina svåra uppgifter och skapa ett tätare samarbete som även kan främja Norden i det internationella arbetet.

Det Nordiska Ministerrådet om fattar flertalet pol itikområden vilket ger goda för utsättningar för att $m$ inisterrådet ska kunna bidra till a rbetet med en utveckla en sammanhållen och ekosystembaserad havsförvaltning och havsplanering i de nordiska lände rna. I ministerrådets olika samarbetsgrupper finns huvudsakligen de sektorer och myndigheter representerade som är väsentliga för denna uppgift.

Ad hoc gruppen föreslår att Nordiska Ministerrådet aktivt arbetar vidare inom följande områden 


\subsection{Bidra till en sammanhållen ekosystembaserad havsförvaltning}

Det råder bred enighet bland länderna om att ekosystemansatsen bör vara en grundläggande utgångs punkt i förv altningen av havsm iljön och de marina resurserna. För att de kom plexa och sektorsövergripande havsmiljöfrågorna ska kunna tas om hand kräv s en enhetlig, övergripan de och sammanhållen förvaltning som säkerställer att miljön beaktas även inom andra politikområden och samhällssektorer.

De nordiska länderna bör förstärka sitt samarbete för att skapa en ekosystembaserad och sammanhållen havsfö rvaltning. Det Nordiska Ministerrådet bör ha en central roll i detta arbete.

\subsection{Arbeta aktivt för att utveckla havsplaneringen}

En ändamålsenlig planering av havsområdena är ett viktigt verktyg för en god skötsel av haven. Några nordiska länder har planeringssy stem för att ange o mråden för aktiviteter till havs som sjöfart, oljeutvinning, fiske m.m. medan andra inte utvecklat så dana. De nordiska länder står dock alla inför uppgiften att införa helt äckande planeringssy stem för samtliga sina havso mråden so $\mathrm{m}$ är sektorsin tegrerade och som ger avvägningar mellan skydd och utny ttjande av havet. Behovet av en ekosystembaserad och sektorsövergripande havsplanering är särskilt ty dligt $\mathrm{i}$ hårt utnyttjade och belastade landomslutna regionala hav som Östersjön och Nordsjön.

Det Nordiska Ministerrådet bör verka för att skapa ett ökat sa marbete mellan länderna när de ut vecklar planering av sina havsområden och bör finna fastare former för det samarbetet.

Ministerrådet bör verka fö $r$ att havsplaneringen grundas på ekosystemansats och sektorsintegrering, för att planeringsinsatserna bli samordnade och för att det utveckl as planeringsmetoder och planeringsunderlag som är tillämpliga för de olika regionala havsområdena.

\subsection{Verka för pilot- och samarbetsprojekt för förvaltning och planering av havet}

I ett läge $d$ är de flesta nord iska länder saknar erfarenhet av utv ecklad förvaltning och planering av sin a havsområden men ändå inom en snar framtid behöver tillsk apa sådana sy stem $\mathrm{k}$ an pilot- och samarb etsprojekt ge värdefulla erfarenheter och principer och metoder prövas och förankras hos myndigheter och aktörer. Inom EU oc h i tidig are projekt finn s förslag och idéer som bör prövas och vidareutvecklas i praktisk tillämpning. 
De havso mråden som framstår so $\mathrm{m}$ sä rskilt läm pliga för pilot- och samarbetsprojekt är Kvarken och Bottenhavet, Skärgårdsom rådena mellan Stockholm, Åland och Åbo samt Kattegat och S kagerrak. I Östersjön bör Nordiska Ministerrådet ingå i ett samarbete med EU-Ko mmissionen, HELCOM, VASAB och andra relevanta pa rter om utförande av pilotprojekt inom ramarna för den kommande Östersjöstrategin och EU:s maritima politik. Även i Nordostatlanten behöver det tas initiativ till läm pliga projekt.

Det Nordiska Ministerrådet bör i sa marbete med andra parter ta initiativ till, och stödja, pilot- och samarbetsprojekt för förvaltning och planering av havet.

Det Nordiska Ministerrådet bör a ktivt söka samarbete med NIB och NEFCO för att skapa finansiering till pilot- och samarbetsprojekt inom Östersjöregionen och därigenom även söka involvera övriga östersjöländer.

\subsection{Främja utbyte av erfarenheter mellan länder i ett Nordiskt Forum}

Det görs f.n. många insatser för att ut veckla olika aspekter av förvaltning och planering av havet $\mathrm{i}$ et $\mathrm{t}$ flertal myndigheter, organisationer m.m. i de nordiska länderna. Det pågår också etablerade samarbeten inom regionala och internationella konve ntioner $m$ en dessa är oftast geografiskt eller sektoriellt begränsade. Det finns därfö $r$ ett behov av att inom Norden skyndsamt bygga upp en sammanhållen kunskap om de skilda insatserna. Det Nordiska Ministerrådet har därför en viktig uppgift med att bi dra till kunskapsutbyte, kompetensutveckling och en gemensam grundsyn i arbetet med förvaltning och planering av havet inom det nordiska området.

I det Nordiska Ministerrådet möjliggörs ett långsiktigt samarbete mellan Östersjö- och Nordsjöregionen över sektorsgränserna. Syftet bör vara att utby ta erfarenheter och kunska per och tillsammans med HELCOM, OSPAR och andra aktörer skapa en gemensam förståelse för behovet av en sammanhållen, ekosystembaserad förvaltning och planering av havet. Det sa marbetet bör innefatta en bred krets av myndigheter och aktörer men särskilt inkludera regeringsre presentanter och $\mathrm{m}$ yndigheter med huvudansvar för utvecklingen i länderna.

Det No rdiska Min isterrådet bör fo rtsätta att utveckla och stödja ett nordiskt samarbete om utbyte av erfare nheter och kunskaper om en sammanhållen och ekosystembaserad förvaltning och planering av havet efter ad hoc grupp ens avrapportering. Ämb etsmannakommitteen för miljöfrågor bör finna former fö r hur Nordiska Ministerrådet skall arbeta vida re med 
dessa frågor. Ett alterna tiv är att Akva tiska ekosystemgruppen får ett utökat ansvar, ett annat är att skapa ett särskilt Nordiskt forum.

\subsection{Havets År 2012}

Ad hoc arbetsgruppen föreslår att år et 2012 görs till Havets År i Norden. Havets År 2012 skall ly fta det nordisk a sa marbetet om havet in $\mathrm{p}$ å den politiska scenen både inom Norden och internationellt. Markeringen skal fungera som en politisk ram för samarb etet om planering och förvaltning av havet fram till 2012, och ge en möjlighet för Norden att presenter a sina ambitioner och resultat i havsm iljösamarbetet. Havets År 2012 skall vara en ram $f$ ör att främja förståelsen av alla de tjän ster och värd en som havet ger och därmed visa på dess betydelse för den mänskliga välfärden. Havets år skall understryka betydelsen av det stora arbete som under denna tid genom förs i Norden och $\mathrm{Eu}$ ropa för att främja en sammanhållen och ekosystembaserad förvaltning och planering av havet.

Nordiska Ministerrådet bör markera ha vets stora betydelse för vår a nordiska samhällen genom att utlysa året 2012 till ett Havets Ar för ett ant al mångkulturella och tvärsektoriella evenemang .

\subsection{Främja samarbete och nordiska perspektiv i internationella processer}

För de n ordiska länderna har HELCOM och OSPAR en särställning bland konventionerna inom havsmiljöområdet och de har en central roll i framväxten av en ekos ystembaserad havsförvaltning. De nordiska parterna i vardera av de bägge konventionerna har behov av att få del av det samlade arbetet och inom OSPAR kan finnas behov av att betona ett nordiskt perspektiv. Genom ett utökat sam arbete om havsförvaltning kan de nordiska länderna stödja varandra $\mathrm{i}$ arbetet med att genom föra det marina direktivet och även ramdirektivet för vatten. Geno m samarbetet kan även nordiska intressen och pe rspektiv stärkas i E U:s ha vsarbete liks om nordiska exempel främja detta. De länder och självsty relseområden som inte är medlemmar i EU bör få del av e rfarenheterna av EU-arbetet, t. ex. de initiativ som tas inom ramen för EU:s Östersjöstrategi.

Det Nordiska Ministerrådet bör verka för att de nordiska medlem sstaterna samarbetar för ett nordiskt per spektiv i EU: s havsarbete samt att de överför erfarenheterna från EU:s ha vssamarbete till de nordiska länder och självstyrande org an som inte är medlemmar $i$ EU. Rådet b ör aktivt följa upp be hovet av kunskapsutby te och samordning särskilt när det gäller ramdirektivet för vatten och det marina strategidirektivet. 
Det Nordiska Ministerrådet bör stödj a de nordiska ländernas aktiviteter inom pågående internationella processer om havsplanering för att säkerställa att planeringsprinciperna $b$ lir tillämpliga för nordiska förhållanden och att ekosystemansatsen blir grundläggande. 



\section{Inledning}

De nordiska länderna ansvarar för stora och viktiga havsom råden, från Östersjön, Västerhavet och Nordsjön till Nordatlanten, Barents hav och de arktiska havsområdena. Varje havso mråde ha r sina egna specifika miljöproblem och utveckl ingsmöjligheter och förutsättningarna för de olika länderna att ta sig an dessa ut maningar skiljer sig avsevärt. Många av dessa frågor är dock ge nerella till sin natur och de nordiska lä nderna har mycket att vinna på att lära sig av varandras erfar enheter. För att länderna ska klara av ut maningarna krävs ett utvecklat sa marbete o ch gemensamma insatser.

Miljöministrarna inom No rdiska ministerrådet beslutade den 4 september 2008 att fördjupa sitt samarbet e och ge en ad hoc-arbetsgrupp i uppdrag att u tarbeta förslag för utveckling och tydligare nordisk samordning av initia tiv till planering, sky dd och förvaltning av ländernas havsområden som omfattar Östersjön, Nordatlanten och delar av Arktis. Syftet är att stärka det nordiska samarbetet o ch ge underl ag för gemensamma initiativ inom EU och i andra internationella sammanhang. Gruppen skulle särskilt:

- ta initiativ till utbyte och sammanställning av erfarenheter på nationell och regional nivå av ekosystembaserad planering och förvaltning av havs- och kustområden,

- belysa möjligheter till fördjupat samarbete om planering och förvaltning av havs- och kustområden, föreslå hur sådant samarbete kan utvecklas och hur förberedelse inför relevanta internationella processer kan utvecklas,

- undersöka möjligheterna till pilotprojekt för god planering och förvaltning av havsmiljön.

De föresl agna initiativen ska stärka det internationella samarbet et och konventionerna på havso mrådet samt främja erfarenhetsutbyte och samordnat agerande i internationella processer. Den stora geografiska utbredningen av de nordiska ländernas havs områden innebär att gruppens förslag och de nordiska initiativen kan ge bidrag till och påverka flera internationella samarbeten $\mathrm{o} m$ haven så att dessa $\mathrm{t}$ ar hänsyn till de nordiska havsområdenas förhållanden och främj ar fortsatta nordiska ansträngningar att utveckl a arbetet med förvaltn ing och planering av havsområdena. Det gäller i särskilt hög grad EU som nu är i en intensiv fas med att lägga fast en långsiktig politik för de maritima frågorna men även de regionala havskonventionerna som har att f ylla en viktig roll i detta arbete. Även för de nor diska havsområden som inte direkt berörs av EU:s strävande $n$ 
på havspolitikens område finns andra samarbetsorganisationer och grannländer för vilka de nordiska initiativen kan bli inspiration och exempel för utökat samarbete i dessa områden.

Det nordiska samarbetet är ett av världens mest omfattande regionala samarbeten. Det är politiskt, ekonom iskt, kulturell t och värdemässigt förankrat och är en viktig deltagare i europeiskt och internationellt samarbete. Det nordiska ministerrådet har i flera decennier haft en aktiv roll i att stärka det nordiska miljösamarbetet, men ännu finns en lång rad utmaningar på miljöområdet so m måste $\mathrm{m}$ ötas i sam verkan - nationellt, regionalt och globalt. Detta gäller fram förallt klimatförändringarna, användning och utsl äpp av farliga kem ikalier, skydd av havens ekosy stem samt bevarande av den biologiska mångfalden.

Arbetsgruppen bildades av representant er för ministerier och myndigheter i de nordiska länderna och har le tts av den svenska havs miljöambassadören med s ekretariatshjälp från nordiska ministerrådets arbetsgrupp för ak vatiska ekosystem. En redovisning av g ruppens medlemmar finns i bilaga 3. Gru ppen har sa mmanträtt tre gånge $\mathrm{r}$ och $\mathrm{m}$ edlemmar $\mathrm{i}$ den har medverkat i ett antal internationella seminarier och möten.

Den nordiska gruppen har valt att foku sera på hur de nordiska län derna kan samordna sina ansträngningar för hur havet skulle kunna förvaltas som en helhet och på hur ett integrerat och sektorsamordnat planeringssystem skulle kunna utvecklas. Gruppen har inte i detalj behandlat områden eller sektorsfrågor so $\mathrm{m}$ täcks av andra politikområden och processer såsom särskilda miljöfrågor, fiskefrågor, sjöfartsfrågor, etc. Att sekt orerna ska delta i s jälva förvaltningsarbetet och planeringsprocessen är dock självklart och av största vikt för att insatserna ska bli verkningsfulla. 


\section{De nordiska haven}

\subsection{Gemensamma och olikartade problem}

Havet har knutit samman folken i de nordiska länderna sedan urminnes tider. Det har varit den vi ktigaste hand elsleden, en källa för försörjning och en grund för ländernas välstånd. Havsbaserade näringar har stor och för några nordiska länder avgörande betydelse för samhällsekonomin och nordiska länder och företag är världsledande i delar av den havsrelaterade ekonomin. Havet är o mistligt för vår kultur och vårt välbefinnande. Att bo vid kuste $n$ blir allt mer attraktiv $t$ och bad och båtliv är oupplösligt förbundet $\mathrm{m}$ ed vår korta nordiska so mmar. Det intensiva och allt $\mathrm{m}$ er ökande utnyttjandet av kus terna och havet och dess resurser har e mellertid också lett till $\mathrm{m}$ iljöpåverkan och konkurrens $\mathrm{m}$ ellan olika intr essen. Havsmiljön har försäm rats av utsläpp till luft och vatten, i vissa fall i oroväckande grad och lett till ökad sårba rhet för ekosy stemen. Havet har en avgörande betydelse för klim atet och effekterna av den glo bala uppvärmningen kan bli förödande för vissa områden. När all denna påverkan ackumuleras uppstår kritiska tillstånd för vissa känsliga havsområden.

De nordiska havsområdena (Fig. 1) är stora och sträcker sig mellan två kontinenter varför förhållandena varier ar avsevärt och kan sägas omfatta två extre mfall. Nordatlanten och Arktis är vidsträc kta och djupa oceanområden med storskalig betydelse fö $\mathrm{r}$ det globala klim atet, få problem områden som fiske, oljeutvinning oc $\mathrm{h}$ sjöfart, en liten befol kning och relativt begränsad påverkan från la ndområden. Men de hotas av långväga föroreningar, försurning av havet oc $\mathrm{h}$ ett allt varmare och förändrat Arktis. Östersjön å andra sida $n$ är ett begränsat, grunt och sy refattigt innanhav med omfattande bottendöd, en flora och fauna som lever på marginalen i det bräckta vattnet, utsläpp av m iljögifter och näringsäm nen från omgivande landom råden med stor befo $1 \mathrm{kning}$ och i ntensivt markutnyttjande, ökande exploateringar av stränder och grundområden och en starkt växande fartygstrafik med risk för oljeutsläpp. 


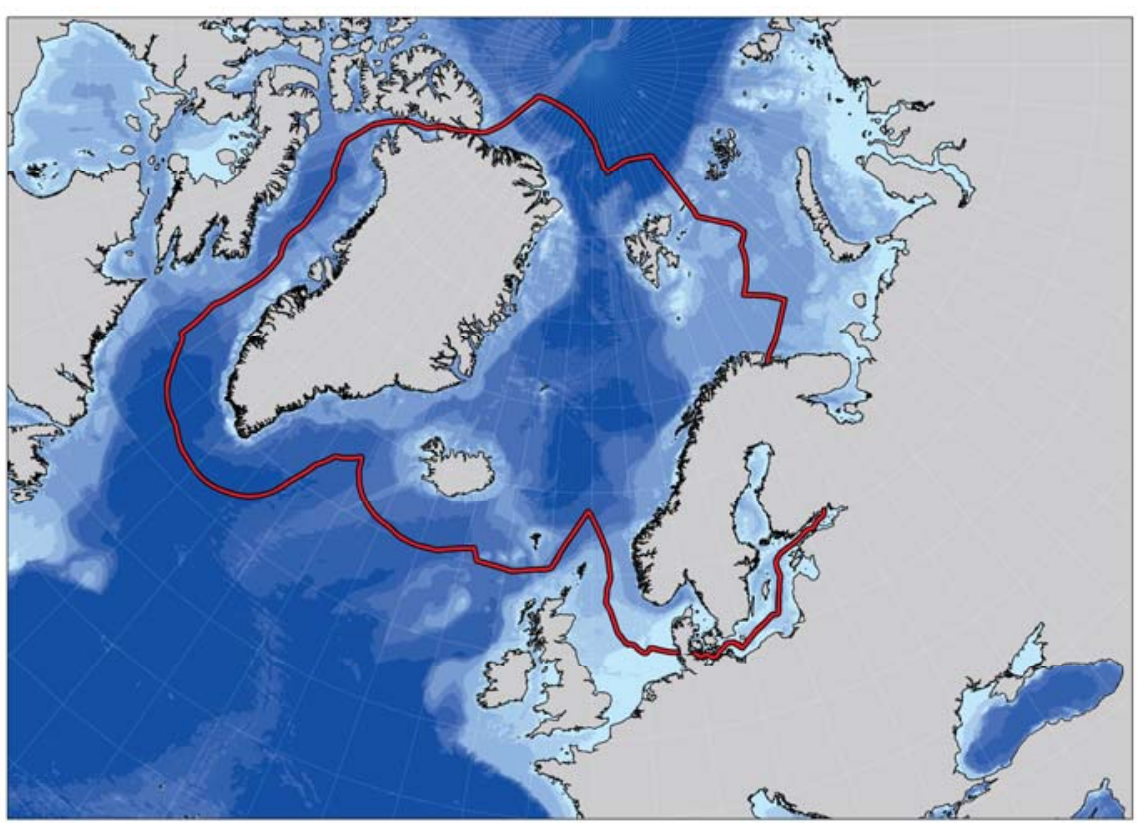

Figur 1. Illustrering av de nordiska havsområdena

\subsection{Stora utmaningar för de nordiska länderna}

De ko mplexa sa mbanden mellan landbaserad e aktiviteter, deras utsläpp till kustvatten och miljöförhållandena i havet liksom de skilda och ökande önskemålen på utn yttjande av havsom rådena har bli vit stora och svårbemästrade utmaningar för $\mathrm{d}$ e nordiska länderna när d e ställs inför uppgiften att ta sig an de $\mathrm{m}$ ångfacetterade problemen med havsom rådena. I länderna saknas i all mänhet en enhetlig förvaltning s om kan ta ett effektivt och sam lat grepp om dessa frå gor. För havsområdena och särskilt utsjöområdena saknas helt en utveck lad och sam ordnad förvaltning. Hittills har hot mot havs- och kustm iljön oftast behandlats sektorsvis eller enbart momentant för viss påverkan. Skagerrak och Östersjön är omslutna av tätbefo lkade landom råden och där är kraven stora på att dagens uppsplittrade och fragmenterade förvaltning övervinner sina traditionella administrativa gränser för att finna gemensamma lösningar som ofta kan ha sin lösning på land. Ut maningarna är annorlun da i de vidsträckta öppna havsområdena i den ar ktiska delen av Norden. Här står man inför e n mer storskalig pro blematik men liksom för de övriga om rådena bör man med en sammanhållen och ekosy stembaserad förvaltning kunna fokusera på den viktigaste påverkan och föreslå förvaltningsmässigt kostnadseffektiva rekommendationer och regleringar. 
Tabell 1. Sammanställd nyckelinformation gällande förvaltning och planering av havsområden i Norden. I tabellen återges ägoförhållanden, ansvariga myndigheter, planerings-/förvaltningsplaner samt lagstiftning i de nordiska ländernas territorialvatten (Terr.) och ekonomiska zon (Ekon). (Övriga förkortningar: BL= baslinje, $\mathrm{nm=}$ sjömil, WFD= ramdirektiv för vatten).

\begin{tabular}{|c|c|c|c|c|c|c|c|c|c|c|c|c|c|c|c|c|c|}
\hline & & \multicolumn{2}{|c|}{ Finland } & \multicolumn{2}{|c|}{ Sverige } & \multicolumn{2}{|c|}{ Norge } & \multicolumn{2}{|c|}{ Danmark } & \multicolumn{2}{|c|}{ Island } & \multicolumn{2}{|c|}{ Åland } & \multicolumn{2}{|c|}{ Färöarna } & \multicolumn{2}{|c|}{ Grönland } \\
\hline & & Terr. & Ekon. & Terr. & Ekon. & Terr. & Ekon. & Terr. & Ekon. & Terr. & Ekon. & Terr. & Ekon. & Terr. & Ekon. & Terr. & Ekon. \\
\hline \multirow[t]{3}{*}{ 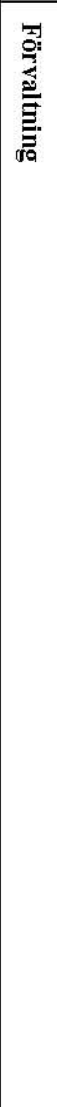 } & 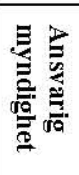 & $\begin{array}{l}\text { Staten } \\
\text { Vattendi } \\
\text { strikt }\end{array}$ & Staten & $\begin{array}{l}\text { Staten. } \\
\text { Fem } \\
\text { vattendistri } \\
\text { kt. BL+1 } \\
\mathrm{nm} .\end{array}$ & $\begin{array}{l}\text { Ingen } \\
\text { övergripan } \\
\text { de } \\
\text { myndighet. }\end{array}$ & $\begin{array}{l}\text { Kommuner } \\
\text { innanför BL, } \\
\text { Staten } \\
\text { utanför }\end{array}$ & Staten & $\begin{array}{l}\text { Staten / Fyra } \\
\text { vattendistrikt }\end{array}$ & $\begin{array}{l}\text { Statlig } \\
\text { förvaltning } \\
\text { av enskilda } \\
\text { sektorer }\end{array}$ & $\begin{array}{l}\text { Kommuner } \\
\text { innanför } \\
\text { 115.m. Staten } \\
\text { utanför }\end{array}$ & Staten & $\begin{array}{l}\text { Alands } \\
\text { Landskaps } \\
\text { regering(ut } \\
\text { gör även } \\
\text { vattendistri } \\
\text { kt) }\end{array}$ & \multirow[t]{3}{*}{ 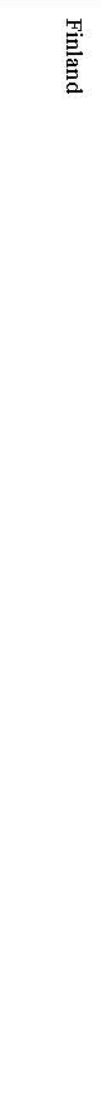 } & $\begin{array}{l}\text { Landsty } \\
\text { ret }\end{array}$ & $\begin{array}{l}\text { Landsty } \\
\text { ret }\end{array}$ & $\begin{array}{l}\text { Staten } \\
\text { (Danmark } \\
\text { och } \\
\text { Grönland) }\end{array}$ & 麃 \\
\hline & 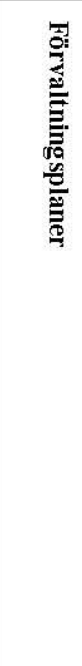 & $\begin{array}{l}\text { Integrer } \\
\text { ade } \\
\text { förvaltni } \\
\text { ngsplan } \\
\text { er, vilka } \\
\text { godkänn } \\
\text { s av } \\
\text { statsråde } \\
\text { t. }\end{array}$ & $\begin{array}{l}\text { Saknas } \\
\text { På } \\
\text { komman } \\
\text { de } \\
\text { planer } \\
\text { för att } \\
\text { uppnå } \\
\text { god } \\
\text { status } \\
\text { enligt } \\
\text { marina } \\
\text { direktiv } \\
\text { et }\end{array}$ & $\begin{array}{l}\text { Förvalt- } \\
\text { ningsplan } \\
\text { antas av } \\
\text { vatten- } \\
\text { distriktets } \\
\text { vatten- } \\
\text { myndighet. }\end{array}$ & $\begin{array}{l}\text { Saknas f.n. } \\
\text { Komman- } \\
\text { de planer } \\
\text { enligt } \\
\text { marina } \\
\text { direktivet. }\end{array}$ & 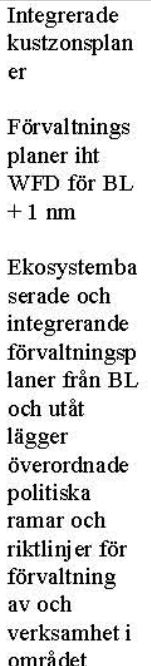 & $\begin{array}{l}\text { Ekosystemba } \\
\text { serade och } \\
\text { integrerande } \\
\text { förvaltningsp } \\
\text { laner }\end{array}$ & $\begin{array}{l}\text { Vatten och } \\
\text { Natura } 2000 \\
\text { planer samt } \\
\text { sektorplaner }\end{array}$ & $\begin{array}{l}\text { Natura } \\
2000 \text { plan. } \\
\text { Sektorspla } \\
\text { ner. } \\
\text { Ingen } \\
\text { samlad } \\
\text { plan. }\end{array}$ & $\begin{array}{l}\text { Ekosystemba } \\
\text { serade och } \\
\text { integrerande } \\
\text { förvaltningsp } \\
\text { laner }\end{array}$ & $\begin{array}{l}\text { Ekosystem } \\
\text { baserade } \\
\text { och } \\
\text { integreran } \\
\text { de } \\
\text { förvaltning } \\
\text { splaner }\end{array}$ & $\begin{array}{l}\text { Förvalt- } \\
\text { ningsplan } \\
\text { antas av } \\
\text { vatten- } \\
\text { distriktets } \\
\text { ansvariga } \\
\text { myndighet. } \\
\text { Därtill } \\
\text { tillkommer } \\
\text { Natura } \\
2000 \\
\text { planer } \\
\text { samt } \\
\text { sektorplan } \\
\text { er. }\end{array}$ & & $\begin{array}{l}\text { Landsty } \\
\text { ret } \\
\text { landsm } \\
\text { yndighe } \\
\text { d }\end{array}$ & $\begin{array}{l}\text { Landsty } \\
\text { ret } \\
\text { /andsm } \\
\text { yndighe } \\
\text { d }\end{array}$ & Saknas & \\
\hline & 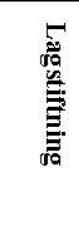 & $\begin{array}{l}\text { EU- } \\
\text { direktiv } \\
+ \\
\text { nationell } \\
\text { a lag } \\
\text { och } \\
\text { förordni } \\
\text { ng }\end{array}$ & $\begin{array}{l}\text { EU- } \\
\text { direktiv } \\
\text { Lagförsl } \\
\text { ag under } \\
\text { bearbetn } \\
\text { ing }\end{array}$ & $\begin{array}{l}\text { EU- } \\
\text { direktiv } \\
\text { Miljöbalk } \\
\text { Nationella } \\
\text { förordning } \\
\text { ar }\end{array}$ & $\begin{array}{l}\text { EU- } \\
\text { direktiv } \\
\text { Sektors- } \\
\text { lagar }\end{array}$ & $\begin{array}{l}\text { EU-direktiv } \\
\text { PBL, } \\
\text { Naturskyddsl } \\
\text { ag (skall } \\
\text { ersättas av ny } \\
\text { naturmångfal } \\
\text { dslag) } \\
\text { Sektorlagar }\end{array}$ & $\begin{array}{l}\text { EU-direktiv } \\
\text { Sektorslagar }\end{array}$ & $\begin{array}{l}\text { EU-direktiv } \\
\text { Sektorreguler } \\
\text { ade. }\end{array}$ & $\begin{array}{l}\text { EU- } \\
\text { direktiv } \\
\text { Sektorregu } \\
\text { lerade. }\end{array}$ & Sektorlagar & $\begin{array}{l}\text { Sektorlaga } \\
\mathrm{r}\end{array}$ & $\begin{array}{l}\text { EU- } \\
\text { direktiv } \\
+ \\
\text { nationella } \\
\text { lag och } \\
\text { förordning }\end{array}$ & & $\begin{array}{l}\text { Havmilj } \\
\text { ölag, } \\
\text { Lag om } \\
\text { kommer } \\
\text { siellt } \\
\text { fiskeri, } \\
\text { Petroleu } \\
\text { mlag }\end{array}$ & $\begin{array}{l}\text { Havmilj } \\
\text { ölag, } \\
\text { Lag om } \\
\text { kommer } \\
\text { siellt } \\
\text { fiskeri, } \\
\text { Petroleu } \\
\text { mlag }\end{array}$ & $\begin{array}{l}\text { Havmiljöa } \\
\text { nordninge } \\
\text { n och } \\
\text { Havmiljöf } \\
\text { örordninge } \\
\mathrm{n}\end{array}$ & \\
\hline
\end{tabular}




\begin{tabular}{|c|c|c|c|c|c|c|c|c|c|c|c|c|c|c|c|c|c|}
\hline & & \multicolumn{2}{|c|}{ Finland } & \multicolumn{2}{|c|}{$\begin{array}{l}\text { Sverige } \\
\end{array}$} & \multicolumn{2}{|c|}{ Norge } & \multicolumn{2}{|c|}{ Danmark } & \multicolumn{2}{|c|}{ Island } & \multicolumn{2}{|c|}{ Åland } & \multicolumn{2}{|c|}{ Färöarna } & \multicolumn{2}{|c|}{ Grönland } \\
\hline & & Terr. & Ekon. & Terr. & Ekon. & Terr. & Ekon. & Terr. & Ekon. & Terr. & Ekon. & Terr. & Ekon & Terr. & Ekon. & Terr. & Ekon \\
\hline \multirow[t]{4}{*}{ 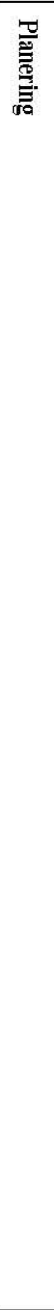 } & $\begin{array}{l}\text { 楉: } \\
\text { 言: } \\
\text { के }\end{array}$ & $\begin{array}{l}\text { Privat } \\
\text { Samfallt } \\
\text { Statligt }\end{array}$ & $\begin{array}{l}\text { Staten } \\
\text { har viss } \\
\text { jurisdikt } \\
\text { ion. }\end{array}$ & $\begin{array}{l}\text { Enskilt vatten } \\
(300 \mathrm{~m} \text { eller } \\
3 \mathrm{~m} \text { djup). } \\
\text { Allmänt } \\
\text { (statligt) vat- } \\
\text { ten utanför. }\end{array}$ & $\begin{array}{l}\text { Staten har } \\
\text { viss } \\
\text { jurisdiktion. }\end{array}$ & Statligt & Staten & Staten & Staten & $\begin{array}{l}\text { Privat } \\
\text { Kommune } \\
\mathrm{r} \\
\text { Statlig }\end{array}$ & Staten & $\begin{array}{l}\text { Privat } \\
\text { Samfällt } \\
\text { Allmänt }\end{array}$ & \multirow[t]{4}{*}{ 䍜 } & Landstyret & $\begin{array}{l}\text { Landsty } \\
\text { ret }\end{array}$ & $\begin{array}{l}\text { Staten } \\
\text { (Danma } \\
\text { rk och } \\
\text { Grönlan } \\
\text { d) }\end{array}$ & \multirow[t]{4}{*}{ 兽 } \\
\hline & 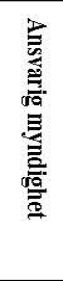 & $\begin{array}{l}\text { Landskaps- } \\
\text { förbund, } \\
\text { Kommuner }\end{array}$ & $\begin{array}{l}\text { Staten } \\
\text { ansvarar } \\
\text {. Ingen } \\
\text { särskild } \\
\text { planerin } \\
\text { gsmeyndi } \\
\text { ghet } \\
\text { utsedd. }\end{array}$ & $\begin{array}{l}\text { Kommunen } \\
\text { ut till } \\
\text { territorial- } \\
\text { havsgränsen. }\end{array}$ & $\begin{array}{l}\text { Staten an- } \\
\text { svarar. Olika } \\
\text { myndigheter } \\
\text { har ansvar } \\
\text { för sin sam- } \\
\text { hallssektor. } \\
\text { Ingen sär- } \\
\text { skild plane- } \\
\text { ringsmyndig- } \\
\text { het utsedd. }\end{array}$ & $\begin{array}{l}\text { Kommuner } \\
\text { till baslinjen } \\
\text { Staten } \\
\text { utanför }\end{array}$ & Staten & 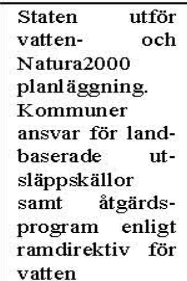 & $\begin{array}{l}\text { Staten } \\
\text { udför } \\
\text { sektorpl } \\
\text { anläggni } \\
\text { ng. }\end{array}$ & 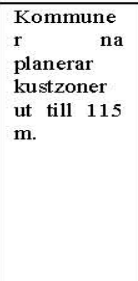 & Staten & $\begin{array}{l}\text { Kommun } \\
\text { Alands } \\
\text { landskaps- } \\
\text { regering }\end{array}$ & & $\begin{array}{l}\text { Landstyret } \\
\text { Aandsmyn } \\
\text { dighed }\end{array}$ & $\begin{array}{l}\text { Landsty } \\
\text { ret } \\
\text { /landsm } \\
\text { yndighe } \\
\text { d }\end{array}$ & $\begin{array}{l}\text { Staten } \\
\text { (Danma } \\
\text { rk och } \\
\text { Grönlan } \\
\text { d) }\end{array}$ & \\
\hline & 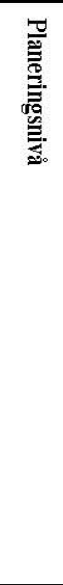 & $\begin{array}{l}\text { Staten: Riks- } \\
\text { omfattande } \\
\text { mål } \\
\text { Landskapsför } \\
\text { bund: Land- } \\
\text { skapsplan } \\
\text { Kommun: } \\
\text { generalplan,d } \\
\text { etaljplan. } \\
\text { Landskapspla } \\
\text { ner med } \\
\text { rättsverkning } \\
\text { ar fastställs } \\
\text { av } \\
\text { miljöminister } \\
\text { iet }\end{array}$ & $\begin{array}{l}\text { Staten } \\
\text { ansvarar } \\
\text { Ingen } \\
\text { särskild } \\
\text { planerin } \\
\text { gsmeyndi } \\
\text { ghet } \\
\text { utsedd. }\end{array}$ & $\begin{array}{l}\text { Kommunala } \\
\text { planer: } \\
\text { översiktsplan } \\
\text { (vägledande, } \\
\text { ej bindande), } \\
\text { områdesbestä } \\
\text { mmelser ooch } \\
\text { detaljplan } \\
\text { (bindande). } \\
\text { Riksintressen } \\
\text { angivna i lag } \\
\text { eller på på } \\
\text { nationell nivå } \\
\text { ska redovisas } \\
\text { i översikts- } \\
\text { planen. }\end{array}$ & $\begin{array}{l}\text { Finns inte för } \\
\text { fysisk } \\
\text { planering. } \\
\text { Statliga } \\
\text { myndigheter } \\
\text { planerar sin } \\
\text { sektors- } \\
\text { verksamhet. }\end{array}$ & $\begin{array}{l}\text { Kommunal } \\
\text { och fylkes- } \\
\text { plan innanför } \\
\text { baslinjen,BL. } \\
\text { Förvaltnings } \\
\text { plan iht WFD } \\
\text { för BL+1 nm } \\
\text { National och } \\
\text { regional } \\
\text { arealplan } \\
\text { (marin } \\
\text { skyddsplan, } \\
\text {-skydds- } \\
\text { områden, } \\
\text { naturreservat, } \\
\text { landskapssky } \\
\text { ddsområden). } \\
\text { Nationala } \\
\text { arealbaserade } \\
\text { förvaltningsp } \\
\text { laner utanför } \\
\text { BL }\end{array}$ & $\begin{array}{l}\begin{array}{l}\text { Helhetliga } \\
\text { arealbasera } \\
\text { de } \\
\text { förvaltning } \\
\text { splaner }\end{array} \\
\text { Arealförva } \\
\text { ltning } \\
\text { innanför } \\
\text { fiskeri- } \\
\text { och } \\
\text { petroleuml } \\
\text { agstiftning } \\
\text { en }\end{array}$ & $\begin{array}{l}\text { Pågånnde } \\
\text { vatten(kvalitets) } \\
\text { planläggning } \\
\text { samt } \\
\text { Naturazoooo } \\
\text { (naturkvalitet). } \\
\text { Ingen fysisk } \\
\text { tvärsektoriell } \\
\text { arealplanläggni } \\
\text { ng. }\end{array}$ & $\begin{array}{l}\text { Statlig } \\
\text { sektorpl } \\
\text { anläggni } \\
\text { ng }\end{array}$ & $\begin{array}{l}\text { Kommuner: } \\
\text { ôversikts } \\
\text { /detaljplan }\end{array}$ & $\begin{array}{l}\begin{array}{l}\text { Finns } \\
\text { inte }\end{array} \\
\text { int }\end{array}$ & $\begin{array}{l}\text { Hierakiskt } \\
\text { plansystem } \\
\text { Landskaps } \\
\text { regering: } \\
\text { samhälsfuu } \\
\text { nktioner; } \\
\text { miliöbeslut } \\
\text { om bästa } \\
\text { platsval } \\
\text { om } \\
\text { etablering } \\
\text { Kommun: } \\
\text { generalpla } \\
\text { n } \\
\text { detaljplan }\end{array}$ & & $\begin{array}{l}\text { Landstyret } \\
\text { /andsmyn } \\
\text { dighed }\end{array}$ & $\begin{array}{l}\text { Landsty } \\
\text { ret } \\
\text { /andsm } \\
\text { yndighe } \\
\text { d }\end{array}$ & $\begin{array}{l}\text { Ingen } \\
\text { overord } \\
\text { nad plan }\end{array}$ & \\
\hline & 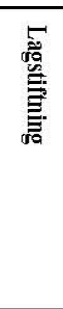 & $\begin{array}{l}\text { Markanvänd } \\
\text { nings- och } \\
\text { bygglagen } \\
\text { täcker sâaual } \\
\text { land- som } \\
\text { havsområden } \\
.\end{array}$ & $\begin{array}{l}\text { Lag om } \\
\text { Finlands } \\
\text { ekonomi } \\
\text { ska zon } \\
\text { och } \\
\text { sektors } \\
\text { lagar }\end{array}$ & 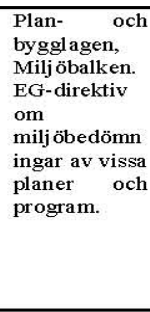 & Sektorslagar & $\begin{array}{l}\text { Plan och } \\
\text { bygglag, } \\
\text { (PBL) } \\
\text { Naturskyddsl } \\
\text { agstiftning, } \\
\text { Sektorslagar }\end{array}$ & $\begin{array}{l}\text { Sektorslag } \\
\text { ar } \\
\text { Förorening } \\
\text { slagen }\end{array}$ & Sektorslagar & $\begin{array}{l}\text { Sektorsl } \\
\text { agar }\end{array}$ & $\begin{array}{l}\begin{array}{l}\text { Sektor } \\
\text { lagar }\end{array}\end{array}$ & $\begin{array}{l}\text { Sektor } \\
\text { lagar }\end{array}$ & $\begin{array}{l}\text { Ålands } \\
\text { plan- } \\
\text { bygglag }+ \\
\text { vatten- och } \\
\text { ovvrig } \\
\text { miljölagsti } \\
\text { ftning }\end{array}$ & & $\begin{array}{l}\text { Sektorregu } \\
\text { lerad } \\
\\
\text { Havmiljöla } \\
\text { g, Lag om } \\
\text { kommersie } \\
\text { lit fiskeri, } \\
\text { Petroleuml } \\
\text { ag }\end{array}$ & $\begin{array}{l}\text { Sektorre } \\
\text { gulerad } \\
\text { Havmilj } \\
\text { ölag, } \\
\text { Lag om } \\
\text { kommer } \\
\text { siellt } \\
\text { fiskeri, } \\
\text { Petroleu } \\
\text { mlag } \\
\text { Sektorre } \\
\text { guleret }\end{array}$ & Saknas & \\
\hline
\end{tabular}


När det gäller förvaltning av vattenområden så har de nordiska länderna som är medlemsländer i EU likartade modeller med statliga myndigheter ansvariga för ramdirektivets genomförande i sin helhet, medan Norge och Island har gett komm unerna ansvar för vatten, land och kustvatt en. På Åland och Färöarna har det regionala självstyret detta ansvar, medan det på Grönland delas mellan regionalt st yre och Dan mark. Förvaltningsplaner för dessa vattenområden tas fra $\mathrm{m}$ i alla nordiska länder och självsty relseområden, utom på Grönland. Fö $\mathrm{r}$ den ekonomiska zonen har staten ansvaret $\mathrm{i}$ alla länder och om råden, men förvaltnin gsplaner har endast tagits fram i Norge. Vad gäller ansvaret för planering av territoralhavet så saknas i flera länder helt äckande och sektorövergr ipande plane ringssystem och situationen skil jer sig be tydligt mellan d e nordiska länderna. Två av de $\mathrm{n}$ ordiska länderna, Finla nd och Sverige, har en ko mmunal, i Finland även regional, pla nering som täcker hela territorialvattnet och är samma som för landom rådena. Planeringsinsatserna gäller dock oftast kust- och skärgårdsproble matiken och mer sällan de öppna havsområdena. I övriga länder har st aten ansvaret för territorialhavet och etab lerade heltäckande planeringssystem saknas. I Norge och på Island har k ommunerna ansvar för inre vatt en respek tive vatten allra närmast kusten. För den ekon omiska zonen sa knar alla länder etablerade planeringssy stem. Norge har som enda nordiskt land tagit sig an de stora öppna hav sområdena och ge nomfört en för de olik a havsområdena succes sivt inrättad förvaltningsplanering. För dessa o mråden (Barentsh avet och Norska havet) finns $m$ arina förvaltningsplaner som ger politiska ram ar och regler för avvägning mellan olika intressen och aktiviteter i havso mrådena. De norska erfarenheterna pekar på att insa tser för förvaltning och planering av stora öppna havsområden kan sammanfalla och att begreppen kan vara svåra att sär skilja. Med si na olika inriktningar och angreppssätt för förvaltning och planering av havet har de nordiska länderna mycket att vinna på att studera varandras exempel och utbyta erfarenheter.

\subsection{Internationellt samarbete om havet}

De olika nordiska länderna ingår i ett antal globala och regionala konventioner och öv erenskommelser och några av dem är medlemmar i EU och de deltar därigenom i en mångfald av internationella sa marbetsprocesser om havet (Fig. 2). FN:s havsrättskonvention är grun dläggande för staternas rättigheter i havso mrådena. I FN:s International Maritime Organisation (IMO) sker sa marbete om sjöfart och sjösäkerhet och $\mathrm{m}$ otverkande av marina föroreningar. Inom $F N$ :s konvention o m biologisk mångfald antogs ett globalt arbetsprogram 2004 vars huvudmål bl.a. är att upprätta nationella och regionala system av skyddade områden till havs år 2012.

Målet för Konventionen om Östersjöomr ådets marina miljö (Helsingforskonventionen) är att åt erställa miljön i Öst ersjöområdet och bevara 
dess ekologiska balans. Samtliga nio Östersjöländer är parter i konventionen och kommissionen HELCOM är tillsatt för att genom föra konventionen och dess aktionsplan för Östersjön som antogs $2007 \mathrm{~s}$ yftar till att god miljöstatus uppnås senast 2021. A ktionsplanen innehåller mål och rekommenderade åtgärder angående övergödning, farliga äm nen, biologisk $m$ ångfald och sjöfart . Som ett led i genom förandet av plan en har Nordiska Investeringsbanken (NIB) oc h det Nordiska Miljöfinansieringsbolaget (NEFCO) tagit initiativ till en mellanstatlig fond för projektidentifiering och projektförberedelser. HELCOM har beslutat att ta fram och pröva principer för storskalig havs planering vilket ska presenter as vid ministermötet våren 2010. Konventionen om skydd av den marin a miljön $i$ Nordostatlanten (OSPAR-konventionen) sy ftar till att förhindra förorening av nord östra Atlanten inklusiv e Nordsjön, Skagerrak och Kattegatt och skydda havsmiljön. En rapport om miljökvaliteten 2010 liksom trender och framtidsutsikter de närmsta 10-20 åren ska läggas fram på ministermötet år 2010. I VASAB - Visi ons and Strategies around the Baltic Sea - är ett mellanstatligt Östersjösamarbete om regional utvecklingsplanering där även Norge och Vitry ssland ingår. I VASAB pågår ett arbete med att ta fram principer för havsplanering.

Arktiska rådet är ett forum för sa mråd och sa marbete mellan regeringarna i de arktiska länderna dvs. de fem nordiska länderna sam t Kanada, Ryssland och USA sam $t$ med representanter för sex organisatio ner för ursprungsfolk i Arktis. Samarbetet gäller till stor del miljöskydd och klimatfrågor. Den Nordostatlantiska Fiskekommissionen (NEAFC) t illvaratar ländernas fiskeriintress en och sa marbetar o $m$ fisk eförordningar $i$ internationella farvatten i nordöstra Atlanten.

Inom EU sker nu en stark fokusering på havet. EU:s ramdirektiv för vatten sy ftar till att föreby gga försämring av y t- och grundvatten och gäller även kustvattnen. God miljöstatus i de olika vattenty perna ska vara uppnådd till 2015 och m edlemsstaterna tar nu fram förvaltni ngsplaner och åtgärdsprogram. EU:s direktiv om marin strateg $i$ syftar till att god miljöstatus ska uppnås i alla havso mråden 2020. Förvaltningspla ner sk a tas fram för de enskilda havsom rådena och tillskapandet av en ekosy stembaserad förvaltning i medlemsstaterna är en cen tralt fråga i direktivet. Direktiv et berör alla nordiska länder och självsty rande områden antingen direkt som medlemsstater eller som tredje land (Färöarna, Island, Grönland, Norge). Norge och Island har ännu inte tagit beslut om genomförande av di rektivet. De regiona la ko nventionerna HELCOM och OSPAR kommer få en tydlig roll i arbetet med att genomföra direktivet.

Kommissionen har presenterat ett meddelande om En integrer ad havspolitik för $E U$ (blåboken) som anger att en havsrelaterad politik inom alla områden måste utarbe tas på e tt samordnat sätt för att bli verkningsfull. Kommissionens åtgärdsplan sy ftar till att skapa länkar mellan olika politikområden. Det marina strategidi rektivet utgör $m$ iljödelen i EU:s marina politik. Fyra övergripande om råden har pekats ut: sty rning, havs- 
planering, information och data sa mt sjöövervakning. Frågorna kommer att behandlas vid Eur opeiska rådets möte i decem ber 2009 då k ommissionen ska presentera de framsteg som skett $\mathrm{i}$ arbetet med blåboken. Inom ramen för havspolitiken har ko mmissionen presenterat ett Meddelande med en färdplan för fysisk planering $i$ kust- och havsområden som sy ftar till att skapa gem ensamma principer för medlemsstaternas planeringsinsatser. Meddelandet diskuteras på ett antal seminarier under året med avslutning i Stockholm. Ko mmissionens rapport o $\mathrm{m}$ arbetet ska därefter behandlas i Rådet. EU har inget mandat för fysisk planering men många direktiv har betydelse för planering av havsom råden. EU-kommissionen kommer inom kort ta fram en EU-strategi för Östersjön vilket är en möjlighet att lån gsiktigt öka EU:s enga gemang i Östersjöregionen. Den förväntas antas hösten 2009. HELCOM:s aktionsplan för Östersjön kommer att $\mathrm{i}$ huvudsak utgöra miljöpelaren i strategin.

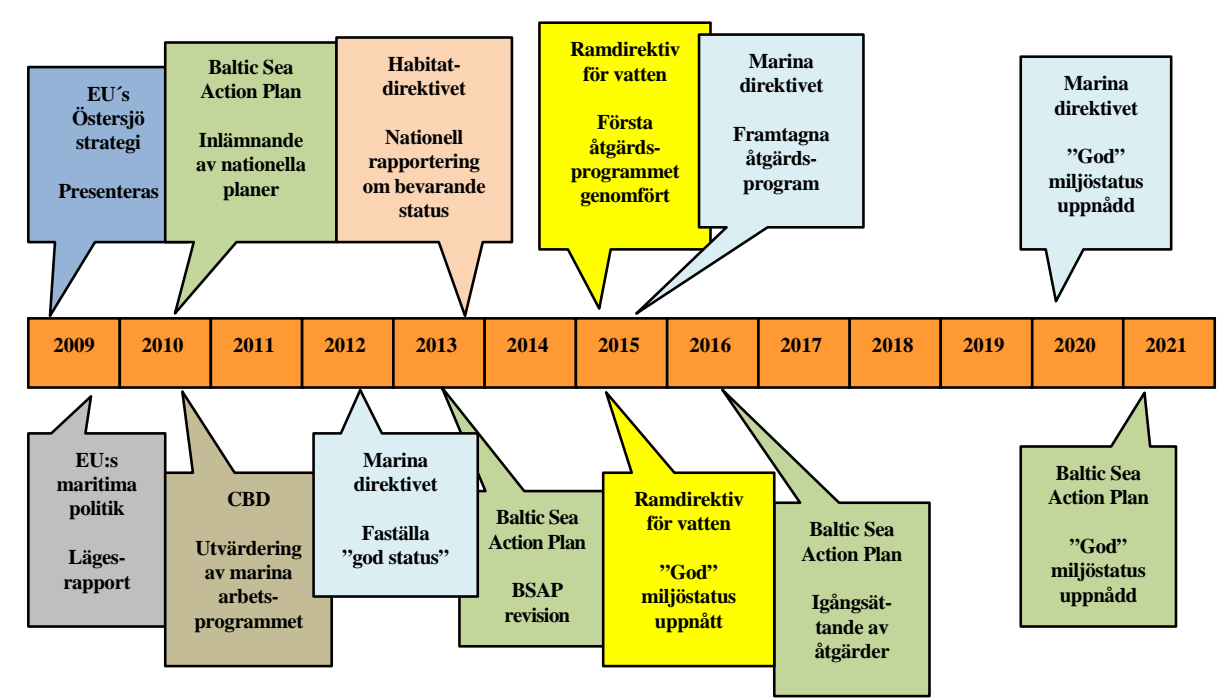

Källa: J. Perus ombearbetat och uppdaterat original av A. Pöhl

Figur 2. Tidsaxel med viktiga datum i internationella och regionala processer. 



\section{Förslag till insatser}

Det Nordiska Ministerrådet om fattar flertalet politikom råden som har relevans för förvaltning av hav, inklusive de sektorer som påverkar havet. Detta ger goda förutsättningar för a tt ministerrådet ska kunna engagera sig i arbetet med en utveckla en sa mmanhållen och ekos ystembaserad havsförvaltning och havs planering i de nordiska länderna. I m inisterrådets olika samarbetsgrupper finns de sektorer och myndigheter representerade so $m$ är väsentliga för denna uppgift, dock saknas kom petensen inom fysisk planering .

De nordiska havsområdena är mycket omfattande sett ur ett europeiskt perspektiv och de innehåller områden av stor miljömässig och ekonomisk betydelse. De nordiska län derna har därför ett stort ansvar för att verka för goda $\mathrm{m}$ iljöförhållanden och långsik tigt hållbart utnyttjande av resurserna i dessa hav. Även om länderna kan skilja sig åt när det gäller förvaltningsstruktur, lagstift ning, EU medlemskap, resurser och miljöproblem i havet så har de i stort $\mathrm{m}$ ycket gemensamt i synen på sköt seln av havet resurser och värden. De står alla inför uppgif ten att skapa legala ramar, ad ministration och verktyg som kan göra dem redo ta sig an de utmaningar som väntar. Länderna bör dä rför dra nytta av varand ras erfarenheter och kunskaper, tillsammans lösa sina svåra uppgifter och skapa ett tätare sa marbete so m även kan främja Norden i det internationella arbetet. Ad hoc gruppen föreslår att Nordiska ministerrådet aktivt arbetar vidare inom de områden som beskrivs nedan (se fig. 2).

\subsection{Bidra till en sammanhållen ekosystembaserad havsförvaltning}

Det råder bred enighet bland länderna om att ekosystemansatsen bör vara en grundläggande utgångs punkt i förv altningen av havsm iljön och de marina resurserna. En sådan förvaltn ing utgår från d et marina ek osystemet och dess funkti oner och processer som t.ex. arter, bestånd, ge netisk variation, livsm iljöer, näri ngskedjor, st römmar liksom framtida u tveckling som följer av t.ex. klimatförändringar. Försik tighetsprincipen ska gälla. Konflikter mellan olika nyttja ndeintressen ska beaktas. Sam rådsprocesser mellan berörda parter ska sä kerställa delaktighet och informationsutbyte. Förvaltningen ska vara sektorsövergripande, integrerad, tvärvetenskaplig och baseras på bästa möjliga kunskap. Förvaltningen bör snabbt kunna anpassas till förändringar som påverkar ekos ystemen. Det 
förutsätter övervakning och förbättrad kunskap om hur olika åtgärder kan påverka havsmiljön.

För att de kom plexa och sektorsöve rgripande havs miljöfrågorna ska kunna tas om hand krävs en enhe tlig, övergripande och sammanhållen förvaltning och planering so $\mathrm{m}$ säk erställer att miljön beaktas även inom andra politikområden och sam hällssektorer. Den bör gälla havsområdena men även ha bäring på landanknut na aktiviteter som påverkar havsmiljön vilket är särskilt angeläget för Öste rsjön och Nordsjön-Skagerrak. Havet är gränsöverskridande och en ändamå lsenlig förvaltning kräver internationella insatser och sam verken. Särskilt Östersjöproblematiken och dess lösningar för utsätter ett $u$ tvecklat samarbete mellan länderna och god nationell förankring.

De nordiska länderna bör förstärka sitt samarbete för att skapa en ekosystembaserad och sammanhållen havsfö rvaltning. Det Nordiska Ministerrådet bör ha en central roll i det samarbetet.

\subsection{Arbeta aktivt för att utveckla havsplaneringen}

En ändamålsenlig planering av havsområdena är ett viktigt verktyg för en god skötsel av haven. De flesta lände rna har redan olika ad ministrativa system för at $t$ ange o mråden för exe mpelvis sjöfart, olje- och gas utvinning, vindenergi, akvakultur och fiske, men dessa tilläm pas ofta sektorsvis och ad hoc-mässigt. Endast ett fåtal av de nordiska länderna har integrerade och sektorsövergrip ande planeringssystem för sina havsområden, som ger avvägning mellan skydd och utnyttjande av havet och dess resurser. Syftet med havsplaneringen bör va ra att främja en långsiktigt hållbar utveckling av haven, åstadkomma en god hushålln ing med havsresurserna, värna och förbättra havsm iljön, tillgodose vikt iga sam hällsintressen och minska risken för intr essekonflikter samt ge en sam lad bild av anspråk och skyddsbeho v. Havsplaneringen kan inte ersätta enskilda sektorers strategiska och operationella $\mathrm{pl}$ aner, men den kan ge en överordnad ram som säkrar samexisten s och ger färre konflikter mellan sektorer och näringar, gör avvägningar mellan utvecklings- och skyddsintressen och ger $m$ öjlighet att identifie ra de mest kostnadseffektiva åtgärderna och regleringarna av verksamheter och aktiviteter.

De nordiska länderna står alla inför uppgiften att införa planeringssy stem för sina havsområden, i vissa $f$ all för hela o mrådet, $i$ andra fall för den ekonomiska zonen. Den grundläggande synen på planeringsbehoven är i stort densamma men förhållande na skiljer sig vad gäller legal och administrativ bas. De plan eringssystem som redan fi nns kan troligen behöva ses öve r när en verksam havsförvaltning införs och när system för den ekonomiska zonen skapas. Länderna har mycket att vinna på att samarbeta när de utformar sina system. Havet är en delad resurs och ett delat 
ansvar. Förhållandena till havs känner inga gränser och de ad ministrativa gränserna $i$ havet bör inte leda till väsensskilda planer utan man bör sträva efter att de så långt möjligt bör vara likartade och sam ordnade. Länderna bör därför sam ordna sina plan eringsinsatser för sa mma re gionala havsområden och särskilt när deras områden gränsar till varandra. Behovet av en verksam och sek torsövergripande havsplanering är särsk ilt tydligt $i$ hårt utnyttjade och belastade landomslutna regionala hav som Östersjön och särskilt i m indre havsom råden som Skagerrak, Kattegatt, Bottenhavet och Bottenviken.

Det saknas i stort ett utvecklat och heltäckande underlag för planeringen och länderna behöver samarbeta för att ta fram info rmation om ekologiska samband, naturförhållanden och anspråk på utnyttjande. För att uppnå speciella förhållanden som t.ex. skydd för särskilda värden i vissa gemensamma havsområden krävs gemensamma initiativ och uthållig samverkan. Det behövs även utvecklas ändamålsenliga planeringsmetoder.

Det Nordiska Ministerråd et bör verka för att skapa ett ökat samarbete mellan länderna när de utvecklar planering av sina havsområden och bör finna fastare former för det samarbetet.

Ministerrådet bör verka fö $r$ att havsplaneringen grundas på ekosystemansats och sektorsintegrering, för att planeringsinsatserna bli samordnade och för att det utveckl as planeringsmetoder och planeringsunderlag som är tillämpliga för alla nordiska länder.

\subsection{Verka för pilot- och samarbetsprojekt för förvaltning och planering av havet}

I ett läge där de flest a n ordiska länder saknar erfarenhet av utvecklad förvaltning och planering av havet men ändå inom en snar framtid behöver tillskapa sådana sy stem är det nödvändigt att genom pilotprojekt snabbt skaffa sig nö dvändiga kunskaper. Genom pilotprojekt kan värdefulla erfarenheter vinnas och princi per och metoder prövas och förankras hos myndigheter och aktörer. Inom EU och i tidigare projekt finns förslag och idéer so $m$ bör prövas och vidareutvecklas i $\mathrm{p}$ raktisk tillämpning. I projektform kan underlag tas fram och samarbete för havsförvaltning och planering utvecklas. Olika nationella system kan jämföras och förslag till samordning utvecklas. Det Nordiska Ministerrådet bör ta initiativ till sådana projekt och stödja dem politisk t och finansiellt. Stöd bör sökas även från andra finansiärer so m EU-Kommissionen och strukturfonderna och samarbete ske med övriga nordiska organisationer. De havso mråden som framstår som särskilt läm pliga för pilotprojekt är Kvarken och Bottenhavet, Sk ärgårdarna från Stoc kholm-Åland-Åbo och Kattegat och 
Skagerrak. Även i nordost Atlanten behöver det tas initiativ till läm pliga projekt. För närmare beskrivning av föreslagna projekt se bilaga 2 .

Det Nordiska Ministerrådet bör i sa marbete med andra parter ta initiativ till och stödj a pilot- och samarbetsprojekt för förvaltning och planering av havet.

Det Nordiska Ministerrådet NMR bör aktivt söka samarbete med NIB och NEFCO för att skapa finansiering till pilotprojekt inom Östersjöregionen och därigenom även söka involvera övriga östersjöländer.

\subsection{Främja utbyte av erfarenheter mellan länder i ett Nordiskt Forum}

Det görs f.n. många insatser för att ut veckla olika aspekter av förvaltning och planering av havet av ett flertal myndigheter, organisationer m.m. i de nordiska länderna. Det pågår också etablerade samarbeten inom regionala och int ernationella konventi oner. Det är viktigt att säkra goda kopplingar mellan arbete som sker na tionellt, regionalt och på EU-nivå och det finns därför ett behov av att in om Norden skyndsamt bygga upp en sammanhållen kunska $\mathrm{p}$ om behov en och de s kilda insatserna. Det Nordiska Ministerrådet har därför en viktig uppgift med att bidra till kunskapsutbyte, kom petensutveckling och en gemensam grundsyn i arbetet med förvaltning och planering av havet inom det nordiska området.

I det Nordiska Ministerrådet möjliggörs ett långsiktigt samarbete mellan Östersjö- och Nordsjöregionen över sektorsgränserna. Syftet bör vara att utby ta erfarenheter och kunska per och tillsammans med HELCOM, OSPAR och andra aktörer skapa en gemensam förståelse för behovet av en sammanhållen, ekosystembaserad förvaltning och planering av havet. Det sa marbetet bör innefatta en bred krets av myndigheter och aktörer men särskilt inkludera regeringsre presentanter och $\mathrm{m}$ yndigheter med huvudansvar för utvecklingen i länderna.

Ämbetsmannakommitten för miljöfrågor (ÄK-M) bör ta beslut o $m$ det fortsatta utvecklingsarbetets (havsp lanering och -fö rvaltning) pr ioritet innanför existerande resurser och ut arbetar eventuellt ett upplägg för ytterligare resurser.

\section{Två alternativ presenteras.}

Det första alternativet är att ar betsgruppen Akvatiska Ekosy stem (AEG) ges i upp drag att stim ulera och lägga grunden för de nordiska ländernas samarbete $\mathrm{o} \mathrm{m}$ utveckling av en sa mmanhållen och ekosy stembaserad förvaltning och förvaltning av havet efter det att ad hoc gruppens mandat löpt ut i juni 2009. I AEGs mandat för tidsperioden 2009-2012 omnämns 
att gruppen skall arbeta med tema 2. 1. Ekosy stembaserad förvaltning i det nordiska Miljöhandli ngsprogrammet 2009-2012. För att öka AEGs kompetens, speciellt inom planeringsarbetet, föreslås att antalet nationella representanter inom AEG utökas från e $\mathrm{n}$ till två. AEG bör ges ökad medelstilldelning och möjlighet att vid behov bilda en stödjande undergrupp, i form av ett Nordiskt Forum för fö rvaltning och p lanering av havet (se bilaga 1b). Forum et, vars mandat skulle vara tidsbundet (t.ex . $2009-$ 2012) skulle kunna läm na förslag till AEG, som därefter beslutar om genomförande och medelstilldelning.

Det andra alternativet är att ett ny tt fristående Nordi skt Forum bildas för att driva dessa frågor sa mt bedöma den kunskapsutveckling $\mathrm{s}$ om behövs för gen omförande av EU:s marina strategidirektiv i de n ordiska länderna liksom för utvecklingen av en ekos ystembaserad planering av havet. Forumet skulle vara tids bundet (2009-2012) och ha en egen budget. Forumet skulle fungera so $\mathrm{m}$ ett cen trum för kunskaps- och erfaren hetsutbyte med fokus olika nationella aktiviteter, goda exempel och erfarenheter från de olika regi onala nordiska haven och kommunicera direkt med Ä K-M. Medlemmarna i foru met b ör represente ra en bred krets av myndigheter, organ och aktörer som är engagerade i frågorna och lämpligen sådana som är verks amma i havs - och kustanknuten förvaltning och planering. Forskning och vetenskap bör även vara representerad.

Ad hoc gruppens förslag till insatser för erfarenhetsutbyte (se bilaga 1a):

- Seminarier för kunskapsspridning och erfarenhetsutbyte, redovisning av goda exempel och för diskussion mellan företrädare för miljösidan och andra berörda samhällssektorer, forskare, intressegrupper m.fl. Seminarierna ska öka förståelsen av en multisektoriell ekosystembaserad förvaltning och planering av havsområden. Seminarier bör lämpligen arrangeras inom teman som; administrativa och rättsliga ramar liksom verktyg och metoder för förvaltning och planering, effekter av klimatändringar och havsförsurning etc. Pågående eller avslutade projektarbeten i de nordiska länderna kan redovisas på gemensamma seminarier så att en mer samlad bild kan skapas av utvecklingsbehoven.

- Workshops för att genom aktivt samarbete utveckla de element och verktyg som behövs för ändamålsenlig förvaltning och planering av havet som exempelvis principer, strategier, riktlinjer, metoder och kunskapsunderlag. Arbetet kan leda till initiering av olika pilotprojekt. Workshops kan även ordnas inom områden som t.ex. socioekonomisk värdering av ekosystemtjänster och åtgärder (Stern analys), genomförandet av marina direktivet, förutsättningar för vindkraftsutbyggnad och energieffektivisering av havsbaserade aktiviteter. Workshops kan även sammanföra och vidareutveckla pilotprojekt och arbete i regionala konventioner och inom EU. 
Det Nordiska Ministerrådet bör fortsätta att utveckla och stödja e tt nordiskt samarbete om utbyte av erfarenheter och kunskaper $i$ arbetet för en sammanhållen och ekosyst embaserad förvaltning och planering av havet efter ad hoc gruppens avrapportering. Ämbetsmannakommitteen för miljöfrågor bör finna former för hur Nordiska Minist errådet skall arbet a vidare med dessa frågor. Ett alterna tiv är att Akvati ska ekosystemgruppen får ett utökat ansvar medan ett annat alternativ är att skapa et $t$ särskilt Nordiskt forum.

\subsection{Havets År 2012}

Ad hoc arbetsgruppen föreslår att år et 2012 görs till Havets År i Norden. Havets År 2012 skall ly fta det nordisk a sa marbetet om havet in $\mathrm{p}$ å den politiska scenen både inom Norden och internationellt. Markeringen skal fungera som en politisk ram för samarb etet om planering och förvaltning av havet fram till 2012 och ge en möjlighet för Norden att presentera sina ambitioner och resultat i havsm iljösamarbetet. Havets År 2012 skall vara en ram för att främja förståelsen av alla de tjänster och värden som havet ger och där med visa på havets bety delse för den mänskliga välfärden. Havets år sk all understryka bety delsen av det stora arbete so $\mathrm{m}$ i detta tidsskede genomförs i Norden och Europa för att främja en sammanhållen och ekosystembaserad förvaltning och planering av havet.

Flera ministerråd och politikområden har, liksom miljösamarbetet, avslut och revid ering av handlingsprogrammen 20 12. Året 2012 är d ärför strategiskt för att markera genomförda insatser och fast nya strategier. Under det första halvåret 2012 är Dan mark ordförande i EU oc h Norge förväntas vara ordförande i Nordiska Mi nisterrådet och Nor disk Råd et. Det är viktigt at t beslut om genomförande av havets år tas på h ög nivå, gärna av sta tsministrarna, så att alla relevanta politikområden involveras i markeringen.

Nordiska Ministerrådet bör markera ha vets stora betydelse för vår a nordiska samhällen genom att utlysa 2012 till ett Havets Ar för ett antal mångkulturella och tvärsektoriella evenemang .

\subsection{Främja samarbete och nordiska perspektiv i internationella processer}

För de nord iska länderna $\mathrm{h}$ ar HELCOM och OSPAR har en särställning bland konven tionerna ino $m$ havsmiljöområdet och de har en central roll i framväxten a v en ekosy stembaserad havsförvaltning. De nordisk a länder som inte är parter i bägge konventionerna har behov av att få del av arbetet $i$ den andra konventionen och i OSPAR ka $\mathrm{n}$ finnas behov av att betona ett nordiskt perspektiv. EU:s arbete med det marina direktivet och den mariti- 
ma strategin $\mathrm{d}$ river på 1 ändernas a rbete $\mathrm{m}$ ed havsförvaltning. Genom e tt utökat samarbete kan de nordiska länd erna stödja varandra o ch un derlätta arbetet med att genomföra det marina direktivet. Även för ramdirektivet för vatten finn s behov av utökat nordiskt samarbete. Geno m samarbetet kan även nordi ska in tressen o ch p erspektiv st ärkas i E U:s h avsarbete lik som nordiska ex empel fr ämja dett a. D e länder och självstyrelseområden so m inte är medlemmar i E U kommer att bli berörda och bör få del av erfarenheterna av E U-arbetet. Om et t fa stare nätv erk mellan EU:s me dlemsstater bildas för havsplanering är det angeläget att de nordiska länderna som ingår i detta verk ar för d e nordiska aspekterna och särskilt för att ekosystemansatsen får gen omslag. I de i nitiativ som tas inom ramen för EU: s Östersjöstrategi bör de nordiska medlemsstaterna verka för att de erfarenheter som kan vinnas även blir värdefulla för övriga nordiska länder.

Det Nordiska Ministerrådet bör verka för att de nordiska medlem sstaterna samarbetar för ett nordiskt per spektiv $i$ EU: s havsarbete samt att de överför erfarenheterna till de nordi ska länder och självstyrande organ som inte är medlemmar $i$ EU. Rådet b ör aktivt följa upp behovet av kunskapsutbyte och samordning särskilt när det gäller ramdirektivet för vatten och det marina strategidirektivet.

Det Nordiska Ministerrådet bör arbeta aktivt inom pågående internationella processer om havsplanering för att säkerställa att planeringsprinciperna blir tillämpliga för no rdiska fö rhållanden o ch att ekosystemansatsen blir grundläggande.

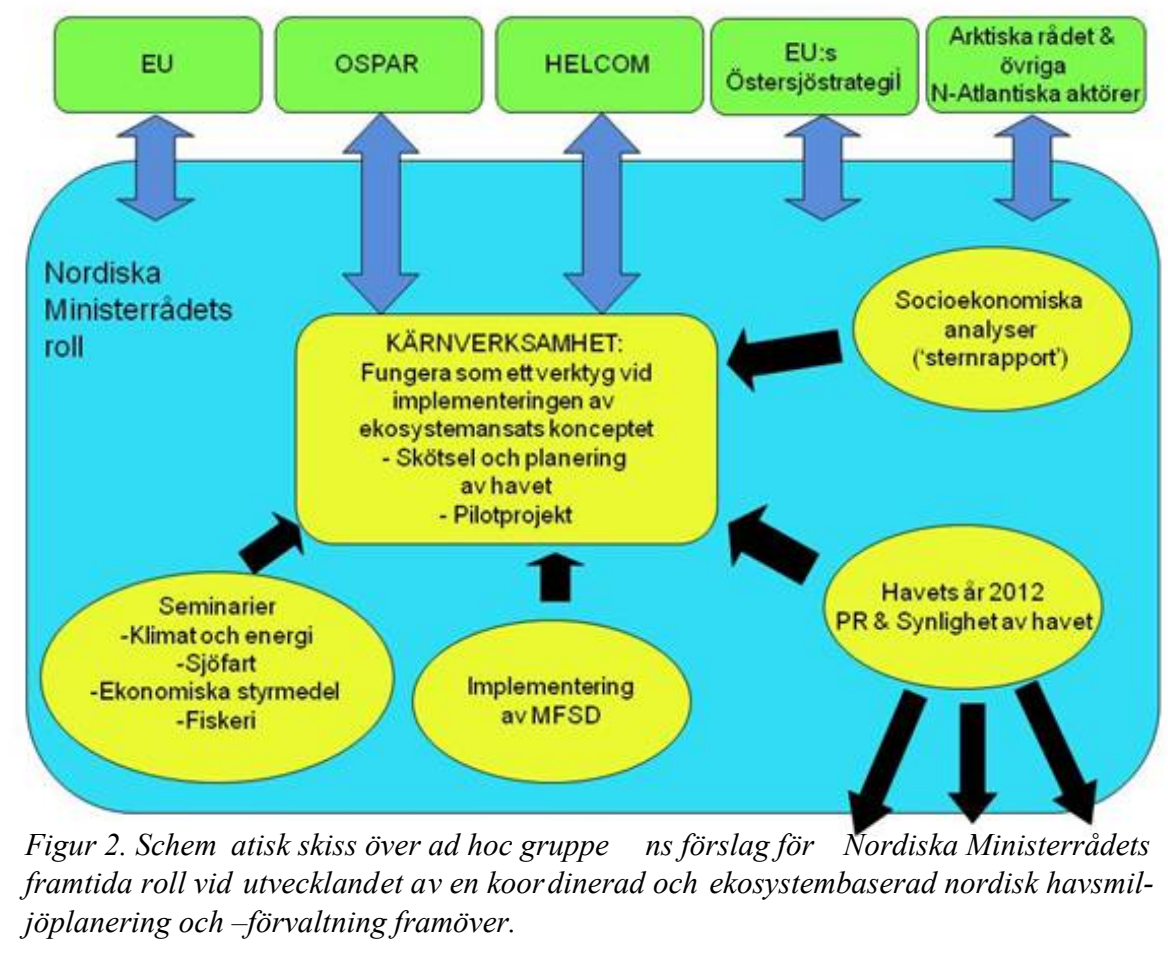





\section{Bilagor}

Ad hoc gruppens planerade och föreslagna aktiviteter

\section{Bilaga 1. Utbyte av erfarenheter}

\subsection{Temaseminarier / Workshops}

1.1.1 . Planering och förvaltning

a) Utveckling av havsplanering och ekosystembaserad förvaltning

b) Seminarieserie på implementeringen av EU's marina strategi

c) "Stern'-analys"

d) Områden i Östersjön som lämpar sig för vindkrafts-

produ ktion

1.1.2 . Klimatförändringar - havsförsurning- luftemissioner

a) Klimatförändringar och havsförsurning

b) Energieffektivisering och reduktion av utsläpp av

klim atgaser från aktiviteter på havet

c) Vilka ekonomiska styrmedel för emissioner från fartygstrafik är praktiskt genomförbara i Östersjön?

\subsection{Nordiskt Forum för planering och förvaltning av marina miljöer}

\subsection{Havets Ar 2012}

\section{Bilaga 2. Pilotprojekt}

\subsection{Kattegat-Skagerrak \\ 2.2. Stockholm-Aland-Äbo \\ 2.3. Kvarken / Bottniska Viken \\ 2.4. Nordostatlanten}

\section{Bilaga 3. Ad-hoc gruppens sammansättning}




\section{Bilaga 1. Utbyte av erfarenheter}

\subsection{Temaseminarier/Workshops}

Det Nordisk a Ministerrådet ska fö rmedla kunskaper oc h erfarenheter, redovisa goda exempel och vara diskussionsfora för företrädare för miljösidan, andra samhällssektorer, forskare och intressegrupper. Seminarierna ska bidra till förståelse för och ökade kunskaper om en sammanhållen och ekosystembaserad förvaltning och plan ering av de $\mathrm{n}$ ordiska have $\mathrm{n}$ i de olika länderna och självsty relseområdena och deras förvaltni ngar och därigenom sk apa en ge mensam bas för deras sa marbete. Seminarier bör ordnas för olika teman som rättsliga ramar, verktyg och metoder, pågående projekt etc. Workshops hålls för att deltagarna genom aktivt samarbete ska utveckla element och verkt yg för förvaltning och planering. Seminarier och workshops kan lämpligen mynna ut i rekommendationer till regionala aktörer so m bl.a. OSPAR, HEL COM, Arktiska rådet m.fl. vilka bjuds in till arrangemangen. Möjliga teman för seminarierna.

\subsubsection{Planering och förvaltning}

Följande förslag på aktiviteter föreslås genomföras av Nordiska Ministerrådet.

a) Utveckling av sammanhållen och ekosystembaserad förvaltning och planering.

- Metoder och styrmedel för förvaltning.

För skapandet av system för en sammanhållen och ekosystembaserad havsförvaltning behövs det tas fram ett många olika instrument. Det handlar om rättsliga regelverk med ändamålsenliga regleringssätt, övervaknings- och uppföljningssystem liksom verksamma samarbetsformer för de berörda aktörerna.

- Planering som verktyg för ekosystembaserad förvaltning.

För att planeringen ska bli ett verkningsfullt verktyg för en ekosystembaserad havsförvaltning bör rättsliga och administrativa system inrättas som baseras på den ekologiska dimensionen. Det nära sambandet mellan förvaltning och planering innebär att systemen bör byggas upp på ett integrerat sätt. Principer, regleringssätt, rättsverkan och medverkan av sektorerna m.m. är frågor som kan diskuteras utifrån bl.a. befintliga planeringsinsatser, projekt och arbeten som t.ex. EU:s, HELCOM:s och VASAB:s förslag till principer för havsplanering.

- Samverkande planering för kust och hav. Det behövs utvecklas former och metoder för hur planering av kusten respektive havet kan samverka. Ländernas olika system och erfarenheter ger möjlighet till fruktbart utvecklingsarbete där även erfarenheter inom EU kan bidra. Sambandet med vatten- och havsförvaltningen bör vara grundläggande i det arbetet. 
b) Seminarieserie om genomförandet av EUs direktiv om marin strategi:

Ad hoc gruppen föreslår att det Nord iska Ministerrådet ordnar seminarier som stöd för det pågående genom förandet av EU:s direktiv om marin strategi utifrån erfarenheterna av motsvarande arbetet med genomförande av EU:s ramdirektiv för vatten. Se minarierna bör behandla hur man kan ange god m iljöstatus, deskriptorer, mål och indikator er likso m hur uppbyggnad av miljöövervakning kan ske. Seminarierna bör ge möjlighet för samnordiska förslag i inte rnationella processe $r$ där direktivet och havsförvaltning är centrala. Seminarieserien skulle kunna genomföras under tre år och ko mbineras med projekt finansierade av den Akvatiska Ekos ystemgruppen och utförda $u$ nder den tid som serien varar. Sem inariernas målgrupp bör vara de nordiska myndigheter, sektorsföreträdare o ch experter som är ansvariga för och berörd a av direktivet sa mt representanter från de regionala havskonventionerna HELCOM och OSPAR.

c) Analys av ekosystemkostnader och värden ('Stern' analys")

Workshops bör ordnas med s yfte att kl argöra definitionen av vad artikel $8 \mathrm{c}$ i det marina strategidirektivet anger om en ekonomisk och social analys av utnyttjandet av dessa vattnen och de kostnader som förstörelsen av den marina miljön för med sig. Resultatet kan vara ett gemensamt utarbetat nordisk förslag so $\mathrm{m} \mathrm{k}$ an föras fram i EU:s arbete med definitionen. Frågan om samordning av finansieri ng av analy serna och det fortsatta arbetet bör också behandlas. Arbete bör ske i s amarbete med HELCOM HOLAS och OSPAR EIHA som kommer att ta fram samhällsekonomiska analyser.

d) Områden i Östersjön som lämpar sig för vindkraftsproduktion

Intresset för att bygga vindkraftsanläggningar ökar stadigt i nordiska länder och de $b$ ästa möjligheterna att utny ttja vind kraften finns oft ast vid kusten eller i havet. Grun da områden i havet är särskilt eftertraktade och de ligger ibland i gem ensamma havs områden. Det krävs en bättre samverkan mellan länderna för att utifrån tekniska, ekonomiska, hushållnings och miljömässiga skäl komma fram till vilka områden som är lån gsiktigt lämpliga. En workshop bör ordnas so $m$ tar de relevanta frågorn a för en sådan samverkan.

\subsubsection{Klimatförändringar - Havsförsurning - Luftemissioner}

a) Klimatförändringar och havsförsurning

Klimatförändringarna ko mmer med stor sannolikh et att påverk a våra möjligheter att utnyttja havet och dess resurser och förutsättningarna kan förändras för många samhällssektorer s om exempelvis sjöfart med hamnar och farleder, fiske och fiskodli ng, turism och rekreation. Klimatförändringarna kommer också att öka sårbarheten i ekosystemen och därmed förstärka effekterna av andra hot som exem pelvis miljögifter, övergöd- 
ning, utsläpp från skeppsfart och oljeverksa mhet. Utsläpp av klim atgaser gör havsvattnet allt surare och de nordiska haven försuras i snabbare takt än många andra havsom råden vilket kan utg öra ett av de största hoten mot livet i haven i framtiden.

Behovet av kunskaps- och erfarenhets utbyte inom detta o mråde är stort och det Nordiska Ministerrådet har där en viktig roll. Den Akvatiska Ekosystemgruppen planer ar under hösten 2009 en workshop på tem at Klimat-Hav och Ad hoc gruppen före slår att work shopen ges tilläggsresurser för att kunna bidra till bättre förståelse av konsekvenserna av havsförsurning, s timulera till en nödvändi $g$ tvärvetenskaplig hanter ing av temat med ökat fokus på de socioekonomiska konsekvenserna och bidra till bättre samarbete mellan forskare och beslutsfattare. Workshopen kan utmynna i rekommendationer som kan läggas fram i nationella och internationella processer so $\mathrm{m}$ behandlar skydd av $\mathrm{m}$ arina ekosy stem och resurser som t.ex. OSPARs ministerkonferens i 2010.

b) Energieffektivisering och reduktion av utsläpp av klimatgaser från aktiviteter på havet

En workshop bör ordnas om minskning av utsläppet av klimatgaser från aktiviteter på havet genom energieffektivisering särskilt vad gäller fångstmetoder. Aktiviteter på havet har i stor utsträckning enbart olja som energikälla. Detta bety der att redukti oner av utsläpp av klim atgaser från transporter på havet och fiskeri kräv er ett annorlun da angreppsätt än för aktiviteter på land. Det finns troligen stor a möjligheterna till energibesparing, särskilt för fiskebåtar. Efterso $\mathrm{m}$ de olika fångst metoderna ger olika stora utsläpp per kg fisk skulle en studie av de för hållandena ge goda möjligheter att få överblick av möjligheterna till energibesparing. Möjligheterna till energieffektivisering oc $\mathrm{h}$ besparing genom regleringen av fisket bör också behandlas liksom behovet av att knyta samman ett bärkraftigt utnyttjande av havets resurs er med frågan om utsläpp av klim atgaser.

c) Ekonomiska styrmedel för emissioner från fartygstrafik i Östersjön

En workshop bör genom föras om olika former av ekonomiska styrmedel som kan användas för minskning av emissioner från farty gstrafik i Östersjön. Utgångspunkt bör tas i den förvänt ade utvecklingen av trafiken och från IMO:s ny a regler f ör tillåtna em issioner. Workshopen skall belysa den förväntade utveckling en av fart ygsemissioner i Östersjön och övriga nordiska vatten, förväntad effekt av IMO:s ny a be stämmelser och behandla existerande sty rmedel som t.ex. miljödifferentierade farleds- och hamnavgifter, ekonomiska styrmedel för kusttrafiken etc. 


\subsection{Nordiskt Forum för förvaltning och planering av havet}

Ad hoc grup pen föreslår att det No rdiska Ministerrådet NMR ö verväger bildandet av ett gemensamt tidsbundet (2009-2012) Nordiskt For um för samarbete o m förvaltning och planering av havet. Detta foru $\mathrm{m}$ skulle svara för en bredare kompetens än vad AEG har avseende de olika aspekterna hos förvaltning och planering av havet. Det kunde bedöma den kunskapsutveckling som behövs för genomfö rande av EU:s marina strategidirektiv i de nordiska länderna liksom för utvecklingen av en ek osystembaserad planering av havet och funger a so $m$ ett centrum för kunskapsoch erfarenhetsutbyte med fokus olika nationella aktiviteter, goda exempel och erfarenheter från de olika re gionala nordiska haven. Medlemmarna i foru met bör represen tera en bred krets av myndigheter, organ och aktörer som är engagerade $i$ frågorna och lä mpligen sådana so $m$ är verksamma i hav s- och kustanknuten förv altning och planering. Fo rskning och vetenskap bör även vara representerad.

Organisatoriskt kun de For umet ende ra fungera fristående, med egen budget och rapportera direkt till ÄK-M. Alternativt kunde For umet fungera som en undergrupp ti 11 Akvatiska ekosy stemgruppen till vilken Forumet kunde avrapportera resultat samt ge n ya förslag på insatser och projekt.

\subsection{Havets Ar 2012}

Ad hoc arbetsgruppen föreslår att 2012 görs till Havets År i Norden. Havets År 2012 skall lyfta det nordiska samarbetet om havet in på den politiska scenen både inom Norden och internationellt. Markeringen skall fungera som en politisk ram för samarb etet om planering och förvaltning av havet fram till 2012 och ge en möjlighet för Norden att presentera sina ambitioner och resultat i havsm iljösamarbetet. Havets År 2012 skall vara en ram för att främja förståelsen av alla de tjänster och värden som havet ger och därmed visa på dess bety delse för den mänskliga välfärden. Havets år skall understryka betydelsen av det stora arbete so $\mathrm{m}$ vid denna tid genomförs i Norden och Europa för att främja en sammanhållen och ekosystembaserad förvaltning och planering av havet. Havet har i årh undraden varit inspirationskälla för m usik, konst och litteratur och knutit samman de nordiska folken och kulturern a. Dess bety delse för den nordiska kulturen bör understrykas och det ku lturella samarbetet i det Nordiska Ministerrådet bör även involveras i Havets År.

Flera Nordiska ministerråd och politikområden har, liksom miljösamarbetet, avslut och revidering av handlingsprogrammen 2012. Året 2012 är därför str ategiskt för att markera genomförda i nsatser och $\mathrm{f}$ ast ny a strategier. Un der det första halvåret 2012 är Dan mark ordföran de i EU, Sverige i HELCOM och Norge förväntas vara ordförande i Nordiska Ministerrådet och Nordisk a Rådet. No rdiska Ministerrådet och Nordiska Rådet bör samarbeta o m markeringen av Havets År 2012 som kan mani- 
festeras såväl i de nordiska samarbetsorganen som i EU. Det är viktigt att beslut om genomförande av havets år tas på hög niv å, gärna av statsm inistrarna, så att alla relevanta politikområden involveras i markeringen.

\section{Genomförande av Havets År 2012}

Havets År 2012 kommer att vara en överordnad ram för redan existerande projekt och i nitiativ samt en plattform för förankring av ny a initiativ och projekt. De förslag till seminarier, workshops och pilotprojekt som förslås är alla delar av arbetet med förvaltning och planering av havet .

Havets år 2012 ska bidra till arbetet med genomförande av EU:s marina strategidirektiv både nationellt och regionalt som i OSPAR och HELCOM. De nordiska länderna kan sam tidigt i EU vis a hur deras samarbete främjat direktivets genom förande och lyfta fram de arbetsprocesser man genomfört och den nivå man nått $i$ arbetet.

- Det ordnas sidoarrangemang på resp. OSPAR:s och HELCOM:s ministermöten i 2010, som markerar det nordiska samarbetet och inbjuder organisationerna och medlemsländerna till att delta i Havets År 2012.

- Markeringen av Havets År 2012 sker primärt i samband med den marina konferens som avses hållas under det danska ordförandeskapet i EU första halvåret 2012 och även det marina symposium, som hålls i det Nordiska Ministerrådets regi.

Flera ministerråd och poli tikområden har likso m miljösamarbetet avslut och revidering av handlingsprogrammen 2012.

- Under andra halvåret 2012 knyts aktiviteterna till revisionen av det nordiska miljöhandlingsprogrammet och strategier inom andra relevanta politikområden.

- Samarbetet med Nordiska Rådet kunde utmynna i att Nordiska Rådets Natur och Miljöpris i 2012 utdelas som premiering av en särskild insats på det marina området.

Utöver dessa centrala arrangemang bör det övervägas hur det breda samarbetet inom det Nordiska Ministerrådet kan användas för att främja kunskap och förståelse för hav ets betydelse för vår välvärd och vikten av en god förvaltning. Några möjliga aktiviteter är följande.

- Information och utbildningsinsatser för skolor, bibliotek och intressegrupper liksom initiativ för media .

- De nordiska huvudstäderna ligger alla vid havet. Därför kunde havsnaturen "under ytan - nära storstaden" vara föremål för särskild uppmärksamhet och de nordiska huvudstäderna kunde medverka $\mathrm{i}$ aktiviteterna. 
- Det utvecklas en rad gränsöverskridande arrangemang i gränslandet mellan det konstnärliga, naturvetenskapliga, förvaltningsmässiga och näringslivsmässiga. Det kan vara tillställningar, workshops, konserter, utställningar, film m.m. företrädesvis i samband med redan existerande aktiviteter i det nordiska kultursamarbetet.

Utgifterna för genom förande av Havets År 2012 kommer främst att bestå av en rad utgifter för förm edlingskampanjer och m ediaarrangemang. Det uppskattas att dessa kostnader kommer att utgöra ca. 500000 DKK under 2011 och 500000 DKK unde r 2012. Kostnaderna för utarbetande av innehåll i kam panjer och förmedling förutsätts täck as geno $m$ de övrig a aktiviteter som Ad hoc gr uppen har föreslagit genom övriga aktiviteter i Nordiska Ministerrådet, särskilt med anknytning ti 11 arbetsgruppen för akvatiska ekosystem, eller genom andra nordiska eller nationella aktiviteter. Havets År 2012 ska således ses som en samlande ram för ett antal nya och redan existerande aktiviteter.

\section{Bilaga 2. Pilotprojekt}

Ad hoc-gruppen föreslår att det Nordiska Ministerrådet initierar och stödjer pilotprojekt för förvaltning och planering av hav et. Det Nordiska Ministerrådet $\mathrm{h}$ ar fö rutsättningar att $\mathrm{v}$ ara en cen tral aktör so $\mathrm{m} \mathrm{k}$ an svara för kunskapsöverföring och samordning mellan försöksprojekt i Nordostatlanten, Nordsjön och Östersjö n. Geno m pilotprojekten kan de no rdiska länderna vinna $v$ ärdefulla erfarenheter och gemensamt pröva principer, metoder och underlag. I projek tformen $k$ an särskilt former för samarbete $p \stackrel{a}{a}$ nationell, regional o ch lokal niv å utv ecklas. Projekten bör in riktas på d e konkreta kun skapsbehov so $m$ länd erna ställs in för vid geno mförandet av EU:s marina strategidirektiv. De bör äv en behandla och i praktiska försök pröva former för $\mathrm{h}$ avsplanering, lä mpligen med $\mathrm{m}$ yndigheter, organ och aktörer som är eller k an komma att bli c entrala vid g enomförandet av en sådan planering. Där bör principer som tas fram i bl.a. EU och HELCOM tillämpas och fördjupas och särski $1 \mathrm{t}$ fo kus sätt as på hur havsp laneringen kan utvecklas med eko systemansatsen so $m g$ rund. För Östersjön är $d$ et naturligt att projekten utformas så att de så långt möjligt ingår i eller koordineras med arbetet med utveckling och genomförande av EU:s kommande Östersjöstrategi. Ad hoc gruppen har identifierat fyra områden i Norden där det bör finnas goda förutsättningar för det Nordiska Ministerrådet att initiera projekt för förvaltning och planering av havet.

\subsection{Skagerrak-Kattegat}

Skagerrak delas mellan Norge, Danmark och Sverige och är Norge s sydligaste och mest inneslutna havsom råde medan det samtidigt är det havs- 
område i Sverige som har mest atlantiska förhållanden med saltvatten och värdefull bot tenflora och fauna. De tre länderna $h$ ar redan gen omfört samarbete i projektform om Skagerrak, särskilt proj ektet Forum Skagerrak, och det är viktigt att man kan bygga vidare $\mathrm{p}$ å detta och $\mathrm{u}$ tveckla samarbetet. Det kan vara lämpligt att nu fokusera samarbetet på principer och metoder för ekosystembaserad förvaltning och planering. Pilotprojektet bör då särskilt inriktas på uppfyllandet av det marina strategidirektivets krav och studera behovet av underlagsdata, analy ser, kartl äggning m.m. i r elation till dessa k rav. Sambanden med tilläm pningen av ram direktivet för vatten och fågel- och habitatdirektiven liksom andra relevanta direktiv bör lämpligen ingå i pr ojektet. Med Norg es deltagande är det naturligt att erfarenheter från arbete $t$ med de norska havsförvaltnin gsplanerna för större havsområden kommer att utnyttjas.

Även om nya underlagsdata inte kan tas fram i projektet bör samordning av dataunderlaget fö $\mathrm{r}$ Skagerrak liksom analy s av den i nformation som då framgår ingå i projektets uppgifter.

Eftersom arb etet ska utgå från e kosystemansatsen bör kartor och underlag visa d e ekologiska grundför hållandena och de koncept som utvecklats i exem pelvis Interreg-projektet BALANCE kan med fördel prövas. De regionala myndigheterna och organen i Sydnorge, norra Danmark och Västsverige bör vara $\mathrm{c}$ entrala för ledningen av projektet och berörda centrala myndigheter med ansvar för sektorer av betydelse för förvaltning och planering bör medverka.

\subsection{Skärgårdsområdet Svealand - Aland - Sydvästra och södra Finland}

Mellan den svenska Svealandskusten och S ydvästra Finland lig ger ett vidsträckt skärgårdso mråde med det Åländska sjä lvstyrelseområdet i centrum. Flera samarb etsprojekt har genom förts i området, bl.a. inom ramen för de t nordiska Skärgårdssa marbetet so m bedrivits seda n 1978 och är ett av Nordiska ministerrådets åtta gränsregionala sa marbetsområden. Området har särskilt goda förutsättningar för projekt där de två länderna och självsty relseområdet genom gemensamma initiativ om förvaltning och planering kan utveckla arbetssätt för att hantera de frågor som är speciella för skärgårdar i Östersjön. Inom ramen för pilotprojekt et kan man utveckla sy stem för utvärdering av vattenskyddsåtgärder och bygga upp nätverk av skyddade områden för att trygga den biologiska mångfalden. Sjöfart och trafik med fritidsbåtar liksom akvakultur är verksamheter som är viktig a för detta skärgårdso mråde och de bör behandlas i p rojektets arbete med förvaltning där harm onisering av reglering och sty rning kan vara en lämplig fråga. 


\subsection{Kvarken/Bottniska Viken}

Kvarkenområdet i Bottniska Viken är ett avs malnat havso mråde so m avdelar Bottenviken och Bottenhavet. Sam banden mellan den svenska och finska de len är starka och samarbetet mellan ländernas regioner när det gäller havet bör utvecklas i projektform. Målsättningen med ett sådant gränsöverskridande sa marbete är a tt utveckla planeringen och $f$ örvaltningen av de nära förbund na kustvattnen. Projektet kan lämpligen jämföra styrinstrument och lagstiftning i Finland och Sverige och söka gemensamma metoder och s ystem för att samordna planeringen mellan länderna, och ta tillvara erfarenheter av andra liknande projekt i $\mathrm{N}$ orden. Försöksprojektet bör utgå från befi ntliga data och undersöka hur dessa kan utnyttjas på ett m er samordnat sätt. Projektets fo kus bör ligga på utveckling av samordnade och överen sstämmande planeringsinitiativ för kust- och havsom rådena där exem pelvis de gr unda havso mrådena gör regionen intressant för vindenergisektorn. Ett brett tvärsektoriel lt deltagande bör 1 tryggas genom att man involverar de instanser so $m$ är ansvariga för planeringen på olika nivåer i regionen, i såväl territorial vattnen som i den ekonomiska zonen.

\subsection{Nordostatlanten}

De nordöstliga delarna av Atlanten skiljer sig väsentligt från övriga nordiska havsområden De i nnehåller sär skilt viktiga pelagiska fiskbestånd och andra stationära fiskarter av stor ek onomisk betydelse likso $\mathrm{m}$ andra viktiga resurser som olja och gas, samtidigt och sjöfarten ökar i betydelse. Dessa hav karaktärisera s av att ekosystemen stäcker sig över stora områden sam tidigt som förvaltningsorgani sationerna i många av dess a västnordiska länder är s må. Det är därför av vikt att finna förvaltningsm odeller som är anpassade till förvaltningar av begränsad storlek. För en del av förvaltningarna gäller även att deras arbete inte kom mer att domineras av genomförandet av EUs direktiv.

Norge har de senaste åren genonfört ett omfattande arbete med att utarbeta förvaltningsm odeller för st ora havsom råden (Barentshav och Norska havet). De norska förvaltnings planerna karaktärisera s a v att de grundas på e $n$ ekosy stembaserad och sektorsövergripande förvaltning. I de politiskt förankrade planerna redogörs för ramarna för såväl existerande som ny verksamhet $i$ havsområdena och de lägger därmed en grund för samexistens för näringar som fiske, sjöfart, oljeverksamhet, turism m.fl.

Ett pilotprojekt för förvalt ning av Nordostatlanten kan läm pligen utveckla den modell som tag its fram för de norska havsförvaltningsplanerna. Den skulle troligen behöva utgå från en enklare version anpassad till de västnordiska ländernas och självförvaltningsom rådenas mindre förvaltningsorganisationer. Projektet s kulle exempelvis kunna ta fram goda exempel liksom vägledning för sam ordnande förvaltning och planering, kartläggning av bottenhabitat och havsresurser samt ange marina skydds- 
områden. Pilotprojektet skulle även kunna studera utbyte och samordning av underlagsdata och information för de nordostatlantiska havsområdena.

\section{Bilaga 3. Ad-hoc gruppens sammansättning}

\begin{tabular}{lll}
\hline Namn & Organisation & Land \\
\hline Gabriella Lindholm (ordf.) & Miljödepartementet & Sverige \\
Jorid Hammersland & Naturvårdsverket & Sverige \\
Sten Jerdenius & Miljödepartementet & Sverige \\
Anders Alm & Miljödepartementet & Sverige \\
Saara Bäck & Miljöministeriet & Finland \\
Tiina Tihlman & Miljöministeriet & Finland \\
Marianne Kroglund & Statens Forurensningstilsyn & Norge \\
Marit Solheim & Miljøverndepartementet & Norge \\
Henrik Wichmann & By- og Landskabsstyrelsen & Danmark \\
Sesselja Bjarnadóttir & Umhverfisráðuneytið & Island \\
Mikael Wennström & Ålands landskapsregering & Åland \\
Jóhanna Olsen & Umhvørvisstovan & Färöarna \\
Karen A Motzfeldt & Grönlands Hjemmestyre & Grönland \\
Jette Vester & Grönlands Hjemmestyre & Grönland \\
Mette Frost & Grönlands Hjemmestyre & Grönland \\
Ásmundur Guðjonsson & Nordiska Ministerrådet & Nordiska Ministerrådet \\
Jens Perus & NMR/Akvatiska Ekosystemgruppen & Koordinator \\
\hline
\end{tabular}




\section{Summary}

The Ministers of the Environm ent of the Nordic council of Mi nisters decided on S eptember $42008 \mathrm{t}$ o deepen their coope ration and co mmission an Ad Hoc working g roup to develop proposals for the development and clearer Nordic coordination of initia tives for planning, protection and management of their marine areas covering the Baltic Sea, North Atlantic and parts of the Arctic. Th e aim is to strengthen the Nordic cooperation and provide a basis for joint initiati ves within the EU and other i nternational contexts.

The group would particularly:

- Take the initiative for the exchange and compilation of experiences at national and regional levels of ecosystem-based planning and management of coastal and sea areas,

- highlight the opportunities for enhanced cooperation on planning and management of coastal and sea areas, suggest how such cooperation can be developed and how preparation for relevant international processes can be developed,

- explore possibilities for pilot projects on good planning and management of the marine environment.

The Nordic sea areas are very extensive from a European perspective and include areas of great environmental and economic importance. The Nordic countries therefore have a great resp onsibility to promote good environmental conditions and long-term sustainable use of resources in these seas. Although countries may differ in ter ms of management structure, legislation, EU membership, resources and environmental proble $\mathrm{ms}$ in sea areas they share by and large a co mmon view on management of the seas' resources and inherent values. Each country is faced with the task of creating legal fra meworks, administration and tools to make them ready to take on the challenges ahead. Countries should therefore benefit from each others experience and knowledge, and together solve these difficult tasks and create a closer cooperation which can also prom ote the Nordic countries in international efforts.

The Nordic Council of Ministers co mprises the majority of policy areas and this gives the Council good po ssibilities to contribute to the work of developing coherent a nd ecosy stem-based mar ine m anagement and planning in $t$ he Nordic co untries. In the Council's various co-operation groups there is representation from the main sectors and agencies that are essential for this task. 
The Ad hoc working group proposes that the Nordic Council of Ministers actively continues its work on in the following areas:

\subsection{Contribute to a coherent ecosystem-based marine management}

There is bro ad consensus am ong Nor dic countries that the eco system approach should be a fun damental starting $\mathrm{p}$ oint in the management of the marine environment and marine re sources. In o rder for the $\mathrm{c}$ omplex and multidisciplinary $\mathrm{m}$ arine issues $\mathrm{t} \mathrm{o}$ be taken care of, $\mathrm{a} u$ niform, comprehensive and coherent management is neede $d$, ensuring that the marine environment is taken into acco unt in other polic y areas and sectors of society.

The Nordic countries shou ld strengthen their cooperation to create an ecosystem-based and coherent marine management. The Nordic Council of Ministers should have a central role in this process.

\subsection{Work actively to develop maritime planning}

A well adapted planning of the sea areas is an i mportant tool $\mathrm{f}$ or good management of the sea. Some Nordic countries have planning systems for allocating areas at sea for activities such as shipping, oil extraction, fishing, etc. while others have not developed such systems. The Nordic countries ar e, however, all $\mathrm{f}$ aced with the task to introduce com prehensive planning systems for all their marine areas that integrate sectors and provide arbitration between protection an $d$ uses of the $s$ ea. The need for an ecosystem-based and sector-wide mari time planning is particularly evident in heavily used and environm entally affected enclosed regional sea $\mathrm{s}$ such as the Baltic Sea and the North Sea.

The Nordic Council of Ministers should work fo r greater co operation between countries when they develop maritime planning for their sea areas and should find more solid forms for that cooperation.

The Council of Ministers should work for maritime planning being based on an ecosystem approach and sector integration, for planning efforts being coordinated and for the develop ment of planning methods and information for planning that are ap plicable to the different regional sea areas. 


\subsection{Work for pilot- and collaboration projects on management and planning of the sea}

In a situation where most Nordic countries lack experience of advanced management and planning of their marine areas but still in the near future need to estab lish such sy stems, pilot- and cooperation projects can provide valuable experience where prin ciples and methods are tested and given support of authoritie s and stake holders. Within the EU and in various projects there are $\mathrm{p}$ roposals a nd ideas that should be tested and further developed into practical applications.

The se a ar eas which appear to be parti cularly suitable for pilot a nd collaborative projects are the Quark an d the Bothnian Sea, the archipelago area between the Stockholm, Åland and Turku and the Kattegat and Skagerrak. In the Baltic Sea, the No rdic Council of Ministers should take part in cooperation with the European Co mmission, HELCOM, VASAB and other relevant parties on the execution of pilot projects within t he framework of the upcom ing European Union Strategy for the Baltic Sea Region and the EU Maritime Policy. In the North Atlantic there is also a need to take the initiative for appropriate projects.

The Nordic Council of Ministers should, in cooperation with other parties, take the initiative for, and support, pilot-and collaboration projects in management and planning of the sea.

The Nordic Council of Ministers should actively seek the cooperation of NIB and NEFCO to provide funding for pilot- and col laboration projects in the Baltic Sea region and thereby also seek to involve the other Baltic countries.

\subsection{Promote exchange of experiences between countries in a Nordic Forum}

Many efforts are currently made to develop various aspects of management and planning of the sea in a nu mber of authorities, organizations, etc. in the $\mathrm{N}$ ordic countries. Established cooperation within regi onal and international conventions is ongoing, but these co nventions are often geographically or sector limited. There is therefore in the Nordic region a need to rapidly create a coherent unde rstanding of the different efforts. Thus, the Nordic Council of Ministers has an important role to contribute to knowledge sharing, skills devel opment and a co mmon outlook in the work with management and planning of the sea in the Nordic area.

Within the Nordic Counci 1 of Ministers a sector-wide and long-t erm cooperation between the Baltic Sea and North Sea regions is made possible. The ai $\mathrm{m}$ should be to exchange experiences and knowledge and to- 
gether with HELCOM, OSPAR and ot her stakeholders cre ate a c ommon understanding of the need for a c oherent, ecosy stem-based management and planning of the sea. The cooperation should include a broad ra nge of authorities and stakeholders, but especi ally include government representatives and agencies with principal responsibilit y for the developm ent within the countries.

The Nordic Council of Ministers should continue to develop and support a Nordic cooperation o $n$ exchange of experience and knowled ge of a coherent, ecosystem-based management and planning of the sea after the ad hoc working group has presented its report in May 2009. The Nordic committee of senior officials for envi ronmental affairs should fi nd ways for how the Nordic Council of Minist ers shall continue work on these issues. An alternative is to give the Aquatic Ecosystems working group an increased responsibility, another is to create a Nordic forum.

\subsection{Year of the Sea 2012}

The Ad hoc working group proposes that the y ear 2012 is made Year of the Sea in the Nordic countries. The Year of the Sea 2012 shall hig hlight the Nordic cooperation on the sea and place it in the political arena both in the Nordic region and internationally. The notification shall serve as a political framework for cooperation on planning and management of the sea up to 2012, and pr ovide an opport unity for the Nordic countries to present their ambitions and achievements in marine environmental cooperation. The Year of the Sea 2012 sha 11 be a fram ework to promote understanding of all the services and values that the sea provides, and thereby demonstrating its im portance to hu man welfare. The Year of the Sea shall underscore the im portance of the great efforts that currently are made in the Nordic countries and Europe to promote a coherent and ecosystem-based management and planning of the sea.

The Nordic Council of Ministers should highlight t he importance of the sea for our Nordic societies by declar ing the year 2012 to the Year of the Sea for a number of multicultural and cross-sector events.

\subsection{Promote Cooperation and Nordic Perspective in international processes}

For the Nordic countries HELCOM an d OSPAR hold a uni que position among the marine environ ment conventions and the $y$ are central for the progress of an ecosystem based marine management. The Nordic Partners in each of the two conventions are in need of information of the collected 
work and within OSPAR there might be a need fo $r$ stres sing a Nordic Perspective. Throug $h$ enh anced coope ration on marine management the Nordic countries can support each other in the im plementation of the Marine Strategy Directive and of the Water Framework Directive as well. By $t$ his cooperation Nor dic inter ests and perspectives may also be strengthened in the EU's work on marine i ssues as w ell a s Nordic examples may further that work. Those countries and autonomous territories that are not $\mathrm{m}$ embers of the Euro pean Union sh ould be informed of the experiences of work within the EU, for exam ple the initiatives taken within the framework of the European Union Strategy for the Baltic Sea Region.

The Nordic Council of Ministers shoul d encourage the Nordic member states to cooperate in intr oducing a Nordic perspective in the EU 's marine work and to transfer the experience of the EU 's cooperation on marine issues to the Nordic countries and autonomous territories whi ch are not EU members. The Council should actively follow up the need for knowledge sharing an d coordination especially in terms of th $e$ Water Framework Directive and the Marine Strategy Directive.

The Nordic Council of Ministers sh ould sup port the Nordic countries' activities in the ongoing international processes on maritime planning to ensure that the principles for pla nning are applica ble to Nordic conditions and that the ecosystem approach becomes fundamental. 